\title{
CIVIL CONTEMPT AND THE INDIGENT CHILD SUPPORT OBLIGOR: THE SILENT RETURN OF DEBTOR'S PRISON
}

\author{
Elizabeth G. Patterson*
}

Each day in the United States thousands of persons are jailed on charges arising from failure to pay court-ordered child support. Some of them have been convicted of contempt of court, a crime based on willful defiance of the court order. However, most are incarcerated pursuant to the court's civil authority to jail contemnors as a means of coercing compliance with the order. In the case of the civil contemnor, confinement generally occurs without the procedural protections that are available as a matter of right in criminal proceedings. A finding of ability to pay the ordered support is a necessary precedent to both a finding of contempt and the penalty of coercive incarceration. Otherwise, the incarceration can only be characterized as punishment for being poor. Yet many incarcerated child support obligors are indigent, with irregular employment, limited earning potential, no real assets, and questionable ability to pay. A variety of systemic and judicial flaws have coalesced to create a fertile environment for unjustified incarcerations. Prominent among these are serious deficiencies in current civil contempt practice. Restoration of equity and due process to this area will require an array of adjustments in federal and state law, agency practice, and judicial process.

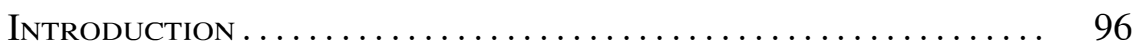

I. The Federal/State Child Support Enforcement

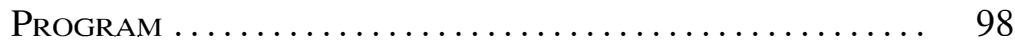

II. The Contempt Power .......................... 101

III. Ability to Pay, Arrearages, and the Indigent

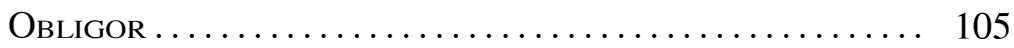

A. Accrual of Large Arrearages by Indigents ........ 105 B.ee Problems in the Setting of Child Support Amounts foreee

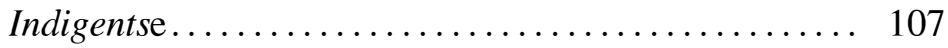

1. Inadequate Information ............... 107

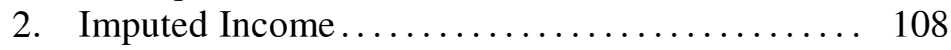

3. Minimum Awards ..................... 109

*ttProfessor, University of South Carolina School of Law. Professor Patterson was Director of the South Carolina Department of Social Services from 1999 through 2003. 
4.ee Retroactive Awards ................................... 110

5.ee Non-Traditional Wage Trajectories ...........e 111

C.eeLimitations on Modification of Supporteee

Awards . eee. ............................. 112

IV .eeArrearages ANd Civil Contempt ................ 115

A. Extent of Incarceration of Indigents ........... 116

The Heavy Burden of Proving Inability to Paye..... 119

C.eeThe Role of Judicial Perceptions andeee

Attitudes .............................. 121

V eeImplications of IMProper Confinement ee.......... 126

A. Social Effects ............................. 126

B.ee Due Process Violations .e..................... £ 27

VI.eeSupporting Children vs. Punishing Poverty: Re-

Calibrating the System ................... 130

VII.e Avoiding Arrearages: Systemic Correctionse....... 131

VIII.e Avoiding Contempt Charges: Intervention ande Compromise ................................. 132

A. Diversion of Contempt Cases ................. 132

B. Bradley Amendment/Forgiveness of Federal Share ... 132e

IX.e Avoiding Imprisonment: Justice in Contempte

Proceedings ................................... 133

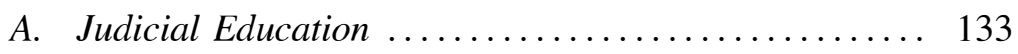

B. Burden of Proofee............................ 134

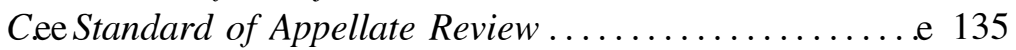

D.eeAssessing Obligor's Credibility ............... 136

E. Representation by Counsele.................. 138

Conclusion.................................... $₫ 40$

\section{INTRODUCTION}

Since becoming the subject of federal legislation in the 1980's, the obligation of absent parents to support their children has assumed a reality that was previously lacking. From 1975 through 2006, more than $\$ 286$ billion in child support was collected and distributed to families. ${ }^{1}$ Federal legislation generated these results by providing states with the monetary resources and legal tools that encouraged and enabled them to identify and locate absent parents and force those parents to provide financial support for their children. These tools ranged from the coercive power of driver's license revocations to the more direct authority to seize wages, tax refunds, and other liquid assets. The ultimate enforcement

1ttOffice of Child Support Enforcement, Child Support Enforcement Fy 2006ttt Preliminary Report 2 (2007), [hereinafter OCSE 2006 Preliminary Report], available at www.acf.hhs.gov/programs/cse/pubs/2007/preliminary_report. 
tool for collecting child support, like any judicially ordered obligation, is imprisonment for contempt of the court's order.

This ultimate sanction is increasingly becoming a routine part of child support enforcement practice. ${ }^{2}$ The widespread use of the contempt sanction derives from the huge amount of outstanding unpaid child support and the large number of obligors who are in arrears on their payments. When other enforcement mechanisms fail to produce the monies owed, states often turn to contempt sanctions in order to punish the non-paying parent, to coerce payment, or both.

When applied to those who are willfully refusing to pay though able to do so, use of the contempt sanction to punish or coerce the recalcitrant parent is an appropriate means of assuring that absent parents take financial responsibility for the children they have brought into the world. However, there is reason to believe that contempt is commonly used in cases involving low-income obligors whose nonpayment may result as much from inability to pay as from willful refusal.

Incarceration of indigent obligors for nonpayment of child support represents a serious failure of the system. It is a social failure because it does little to generate child support payments, and it increases the economic marginalization of the persons whose economic success is critical to achieving the goals of the program. Use of contempt in these situations also drives wedges between family members whose cooperation could significantly contribute to the child's well being. Furthermore, for the large number of indigent fathers who flee to the "underground economy" to avoid their inevitable return to prison, contempt sanctions permanently remove them-usually both socially and economically-from the child's life.

The legal failure represented by incarceration of indigent parents for contempt is-if possible-even greater than the social and economic failure. Criminal contempt is supposed to be a punishment for willful misbehavior, not for an absence of funds. ${ }^{3}$ Civil contempt is supposed to be used to coerce a person to do something that he is able, but unwilling, to do. ${ }^{4}$ In either case, if the contemnor's failure to pay the sums ordered by the court is simply a result of inability to pay, his incarceration can only be characterized as imprisonment for being poor. ${ }^{5}$ The failure of

2 See infra notes 152-65 and accompanying text.

3 See United States v. Bryan, 339 U.S. 323, 329 (1950) (“Ordinarily, one charged with contempt of court for failure to comply with a court order makes a complete defense by proving that he is unable to comply.").

4 See McNeil v. Director, Patuxent Inst., 407 U.S. 245, 251 (1972) (rejecting coercive confinement on a civil contempt theory where individual lacks ability to comply).

5 See In re Warner, 905 A.2d 233, $243-44$ (D.C. 2006) (Schwelb, S.J., concurring) (warning that unrestrained use of the contempt power in child support cases "present[s] a significant risk that a non-custodial parent will face imprisonment on account of poverty"). 
the legal system is magnified in the context of civil contempt because the contemnor does not have the rights in these proceedings that are guaranteed to criminal defendants, including, in many states, the right to counsel.

This Article will examine the forces that have led to this new form of "debtor's prison," with particular focus on the law of contempt. Initially, it will describe the "super-collection agency" approach to child support enforcement mandated by federal law. It will then look at the courts' power to imprison persons for contempt of court, which is the ultimate sanction in the child support enforcement system. The critical importance of establishing the obligor's ability to pay the ordered support before penalizing him or her for contempt will be highlighted. The third section of this Article will examine how the child support enforcement system, as currently structured, creates a large pool of indigent obligors with large child support arrearages that they are unable to pay, and presents evidence that large numbers of these persons are being incarcerated for contempt despite their inability to pay. The fourth section of this Article examines phenomena that underlie this improper use of the contempt power, concluding that procedural hurdles in proving inability to pay and abuse of judicial authority are key causes. Finally, the fifth and sixth sections discuss the social and legal implications of improper confinement of indigent child support obligors, and make suggestions for correcting flaws in the administrative and judicial systems that have led to the current high rate of unwarranted confinement of indigent child support obligors.

\section{I.eeeThe Federal/State Child Support Enforcement Program}

Direct federal involvement in child support enforcement originallyeee was an outgrowth of the welfare program, and its initial effect was limited to families receiving assistance from this program. ${ }^{6}$ Congressional

6 Federal involvement in child support enforcement began in 1965 with legislation providing state and local welfare agencies with access to certain federally held information that would help them locate delinquent child support obligors. Social Security Amendments of 1965, Pub. L. No.89-97, \$340, 79 Stat. 286, 411 (1965) (codified as amended at 42 U.S.C. $\S \S 301,405,1306)$. At that time, enforcement of a parent's obligation to support his or herttt child, like other aspects of family law, was regarded as a matter almost exclusively within thettt jurisdiction of the states, and the federal initiative was merely supportive of the states' efforts.ttt E.g., United States v. Yazell, 382 U.S. 341, 352 (1966). Over the years, however, Congressttt repeatedly amended or supplemented its child support enforcement laws, each time imposingttt more requirements on the states and reducing the states' flexibility to define the substantivettt and procedural parameters of child support law. Eventually, in the Family Support Act ofttt 1988 (FSA-88), Pub .L. No. 100-485, 102 Stat. 2343 (1988) (codified at various sections of 42ttt U.S.C.), and the Personal Responsibility and Work Opportunity Reconciliation Act of 1996ttt (PRWORA), Pub. L. No. 104-193, 110 Stat. 2105 (1996) (codified at various sections of 42ttt U.S.C), Congress established a broad range of substantive and procedural mandates as condi- 
reform of the welfare program in the 1980's focused on two primary techniques for reducing spiraling welfare costs and welfare recipients' economic dependence on government. The first technique was putting the welfare recipient to work. ${ }^{7}$ The second was obtaining support for the recipient's children from absent parents. ${ }^{8}$ Between them, earned income and child support were expected to create sufficient household income so that many single parents - the primary welfare population-would no longer require welfare subsidies. ${ }^{9}$

Child support payments on behalf of children supported by the welfare program also were seen as a means for repaying the state and federal governments for welfare benefits received by the payor's family. ${ }^{10}$ Thus, collections received on behalf of children for whom TANF benefits were being or (in the case of arrearages) had been paid were to be divided between the state and federal governments. ${ }^{11}$ Only when support payments exceeded this debt to the government would the custodial parent/ welfare recipient receive any portion of the funds. ${ }^{12}$ Almost half the national child support debt is owed not to custodial parents, but to the government. ${ }^{13 \mathrm{tt} t}$

In fashioning the child support enforcement program, the federal focus was on creating a relentlessly effective system for collecting as much accrued child support debt as possible from absent parents. ${ }^{14}$ The federal requirements address every aspect of the process of identifying and locating absent parents, and establishing and enforcing the support obligation. Welfare eligibility is conditioned on identification of the fa-

tions for the receipt of federal funds. See Paul K. Legler, The Coming Revolution in Child Support Policy: Implications of the 1996 Welfare Act, 30 FAM. L. Q. 519, 531-35 (1996).

7 See Legler, supra note 6, at 525 n.30.

8 See id. at 521.

9 See id. at 523 n.23, 525 n.30.

10 Id. at 521-22.

11 See 42 U.S.C. $\$ 657$ (2000).

12 This is a simplified rendering of the distribution formula, which varies depending on the source of the funds (e.g., funds obtained by tax intercept are treated differently from other funds), whether they are applicable to current support or to arrears, and whether the custodial parent is a welfare recipient at the time the payment is received. See Id. In addition, states have the option of passing the state share through to the custodial parent. E.g., id. § 657(a)(1); Jan Justice, Ctr. for Law \& Soc. Pol'y, State Policy Regarding Pass-Through and Disregard of Current Month's Child Support Collected for Families Receiving TANF-Funded CASH Assistance (2007), available at www.clasp.org/publications/pass_ through_2007june01.pdf; see also OfFice OF Child Support Enforcement, AT-07-05, ACTION TRANSMirtal (2007), available at www.acf.hhs.gov/programs/cse/pol/AT/2007/at-0705.htm (noting expansion of pass-through options, authorized by Deficit Reduction Act ofttt 2005).t

13 Rebecca May \& Marguerite Roulet, C'tr. for Family Pol’y \& Prac., A Look at Arrests of Low-Income Fathers for Child Support Nonpayment: Enforcement, Court and Program Practices 10 (2005), available at http://www.cffpp.org/publications/ pdfs/noncompliance.pdf.

14 See 42 U.S.C. $\$ \$ 654,666$ (2000) 
ther (in the case of female applicants) and cooperation with efforts to obtain support from the absent parent. ${ }^{15}$ Judicial proceedings for determining paternity and ordering payment of child support have been replaced with administrative proceedings. ${ }^{16}$ Consistency and accuracy ofeee these determinations are to be assured by reliance on genetic testing to establish paternity ${ }^{17}$ and the use of child support guidelines that apply a mathematical formula to calculate the amount of the support award. ${ }^{18 e e e}$

Once the order is in place, collection of the required support is facilitated through a broad array of mechanisms created or mandated by federal law. A vast network of automated systems provides the child support agency with information on obligors' bank accounts, tax filings, and assets, as well as means for effecting automated seizures of certain assets, including tax refunds. ${ }^{19}$ Wage withholding is mandatory in alleee cases where child support enforcement is being handled by the agency. ${ }^{20 e e}$ Employers can be identified through interlinked automated state and national "new hire" directories, to which employers must report information on each newly hired employee. ${ }^{21 e e e}$

If insufficient funds are obtained through wage withholding and seizure of assets, a variety of coercive mechanisms are available to try to induce payment by the obligor. These include the revocation of occupational, ${ }^{22}$ driver's,${ }^{23}$ and other licenses; ${ }^{24}$ the denial of passports; ${ }^{25}$ and reporting of delinquent obligors to consumer reporting agencies. ${ }^{26}$

The federal statute also provides for interstate cooperation in enforcement efforts and creates state and federal "Parent Locate" systems with access to records of departments of corrections, employment security commissions, utility companies, the postal service, the military, and other entities with extensive records on members of the public. ${ }^{27}$

An excellent description of the conceptual underpinnings for federal child support law can be found in an article written by Paul K. Legler, an attorney for the Department of Health and Human Services (HHS) who

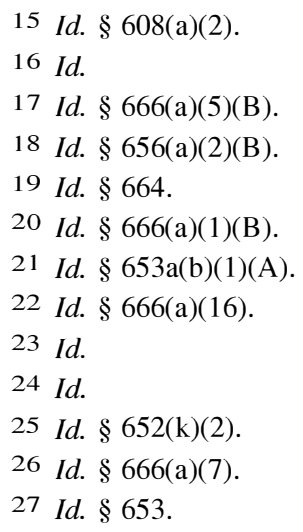


was involved in developing the federal legislation. ${ }^{28}$ According to Legler, the federal model was based on the premise "that the payment of child support should be automatic and inescapable-'like death or taxes." "29 In order to implement this vision, judicial discretion-the prevailing model in most states for determining paternity as well as setting and enforcing support-was to be replaced by expedited administrative proceedings and mass processing of enforcement activities. ${ }^{30}$ "[A]ny delay or failure to make payment should automatically trigger these enforcement actions"; 31 there was no opportunity to make excuses, and no opportunity was necessary since there were no acceptable excuses for nonpayment of support. ${ }^{32}$

This super-collection agency approach to child support enforcement demanded that all available tools be used to extract support payments from recalcitrant parents. When even the vast array of enforcement tools created under the federal legislation failed to bring about payment of child support arrearages, states turned to a mechanism as old as the common law-the judicial power to imprison those in contempt of an order of the court.

\section{The Contempt Power}

Since the twelfth century ${ }^{33}$ courts have claimed inherent authority to protect the integrity of their proceedings and ensure compliance with their lawful orders by holding offending parties in contempt of court. ${ }^{34}$

28 Legler, supra note 6. Paul Legler was, at that time, Attorney Advisor to HHS' Assistant Secretary for Planning and Evaluation.

29 Id. at 538 \& n.93 (quoting Paul K. Legler \& David T. Ellwood, Collecting Fair Support for Children: Getting and Collecting Child Support Obligations (Feb. 1993) (unpublished report)).

30 See id. at 551-54.

31 Id. at 553.

32 It was recognized that there could be exceptional cases, for which the federal model was not appropriate, and it was said that states could maintain limited court-based processes for the collection of support to the extent necessary for these exceptional cases. Id. at 552-53. The exceptional cases that the drafters of the statute had in mind apparently were the cases handled by private divorce attorneys outside the IV-D system, id. at 553, and cases involving obligors who are self-employed or underground and require additional tracking and processing mechanisms beyond those in the mass processing system. Id. at $554 \mathrm{n} .172$.

33 Philip A. Hostak, Note, Int'l Union, United Mine Workers v. Bagwell: A Paradigm Shift in the Distinction Between Civil and Criminal Contempt, 81 Cornell L. Rev. 181 (1995). This power was originally assumed by the royal courts acting under the authority of the monarch.

34 Int'l Union, United Mine Workers v. Bagwell, 512 U.S. 82甘, 83甘 (1994); Earl C. Dudley, Jr., Getting Beyond the Civil/Criminal Distinction: A New Approach to the Regulation of Indirect Contempts, 79 VA. L. REv. 1025, 1070-72 (1993). Contempt of court "is disobedience of an order of a court or conduct which brings the administration of justice into disrespect or which tends to embarrass, impede or obstruct a court in the performance of its functions." In re Contempt of Morris, 674 N.E.2d 761, 764 (Ohio Ct. App. 1996). 
For most of its history, this authority extended to any conduct regarded by the court as contemptuous of its authority, including but not limited to disruption of its proceedings, disobedience of its orders, and criticism of the court or its decisions. The court had exclusive authority to define both the offense and its sanction without appellate oversight, ${ }^{35}$ and there is at least one recorded case in which contempt of court was punished by execution. ${ }^{36}$

This untrammeled contempt power was among the many aspects of the English common law that was received into the law of the independent American states. ${ }^{37}$ It has been only gradually, as conflicts with evolving constitutional values have become apparent, that some of the most egregious aspects of contempt doctrine have been abandoned. For instance, use of the contempt power to silence criticism of the courts and government officials was gradually curtailed, beginning with statutes in the early 1800's ${ }^{38}$ and culminating in the Supreme Court decision in Craig v. Harney in 1947.39 In 1887 the Supreme Court began asserting the power of appellate review of contempt judgments. ${ }^{40}$ Then in 1911, concern about the history of and potential for abuse of the contempt power led the Court to begin a process of limiting courts' unfettered discretion to impose contempt sanctions. ${ }^{41}$

The mechanism used by the Court to introduce constitutional constraints into contempt proceedings was to characterize certain contempts-those that were punitive in nature-as criminal, and hence subject to the substantial procedural constraints imposed on criminal proceedings by the Due Process Clause. ${ }^{42}$ Contempt proceedings characterized as remedial rather than punitive were considered civil in nature, and thus outside the reach of constitutional constraints on criminal proceedings. Civil contempt sanctions are considered remedial because they are imposed to coerce compliance with a court's order, not to punish disobe-

35 "Blackstone stated that 'the sole adjudication of contempts, and the punishment thereof . . belongs exclusively, and without interfering, to each respective Court." Dudley, supra note 34, at 1034 n.30 (quoting Case of Brass Crosby, (1771) 95 Eng. Rep. 1005, 1014 (K.B.)).

36 See Ronald L. Goldfarb, The Contempt Power 15 (1963).

37 Id. at 10.

38 Id. at $19-22$.

39 Craig v. Harney, 331 U.S. 367 (1947).

40 See Worden v. Searls, 121 U.S. 14 (1887); see also Alexander v. United States, 201 U.S. 117, 121 (1906); Bessette v. W.B. Conkey Co., 194 U.S. 324 (1904); In re Christensen Eng'g Co., 194 U.S. 458 (1904).

41 See Gompers v. Buck's Stove \& Range Co., 221 U.S. 418 (1911).

42 Dudley, supra note 34 , at 1033-47 (discussing the civil-criminal distinction as a means for the courts to assert appellate review of some exercises of the contempt power, therefore bringing constitutional constraints to bear on these proceedings). 
dience of it. Although imprisonmenteee

temnor can secure his release at any time by complying with the order. ${ }^{44 t t t}$ Hence, it is said that he "carries the keys of his prison in his own pocket." 45 Criminal contempt, on the other hand, is sanctioned in the same manner as any other criminal offense-by imprisonment for a definite duration, avoidable only through the normal processes of probation or parole. ${ }^{46 t t t}$

The civil contemnor's ability to avoid sanction has been thought to give civil contempt proceedings diminished due process significance. Hence, the Supreme Court has held that these proceedings are not subject to the array of constitutional protections accorded to criminal contemnors and other criminal defendants. ${ }^{47}$ The presumption of innocence, ${ }^{48}$ the state's burden of proof, ${ }^{49}$ and the requirement of proof beyond a reasonable doubt ${ }^{50}$ do not apply in civil contempt proceedings. Indictment and jury trial are not mandated. ${ }^{51}$ Nor does the civil contemnor possess the privilege against self-incrimination, ${ }^{52}$ right to counsel, ${ }^{53}$ or protection against double jeopardy. ${ }^{54}$ Civil contempt sanctions may be imposed using only the most rudimentary elements of due process-notice of the charge and an opportunity to be heard. ${ }^{55}$ Contempts that are classified as civil thus remain largely the domain of the individual judge.

Arguments have been advanced for more stringent constitutional limits on judicial discretion in imposing coercive contempt sanctions. 56 ttt And indeed, the Supreme Court has taken a step in this direction by classifying as criminal the imposition of "coercive" fines for recurrent viola-

43 This Article focuses on imprisonment, the contempt sanction generally used in child support proceedings. However, contempt sanctions can also take other forms, notably fines. See, e.g., Int'l Union, United Mine Workers v. Bagwell, 512 U.S. 821 (1994); United States v. United Mine Workers, 330 U.S. 258 (1947).

44 Shillitani v. United States, 384 U.S. 364, 370 (1966).

45 Gompers, 221 U.S. at 442.

46 See id.; see also Shillitani, 384 U.S. at 370 n.5. ("A criminal contempt proceeding would be characterized by the imposition of an unconditional sentence for punishment or deterrence.").

47 See discussion supra notes 42-46 and accompanying text.

48 Gompers, 221 U.S. at 444.

49 Hicks v. Feiock, 485 U.S. 624 (1988).

50 Id. at 632; Int'l Union, United Mine Workers v. Bagwell, 512 U.S. 821, 826 (1994).

51 Shillitani, 384 U.S. at 370-71; Bagwell, 512 U.S. at 826-27.

52 Gompers, 221 U.S. at 444; Bagwell, 512 U.S. at 826.

53 Bagwell, 512 U.S. at 826.

$54 \mathrm{Id}$.

$55 I d$. at 827. Some states have expanded the procedural protections in civil contempt beyond those required by the Supreme Court; most importantly, several have recognized a right to counsel for indigent civil contemnors. See, e.g., State ex rel. Miller v. Grady, No. 031799, 2005 WL 839409, at *5-7 (Iowa App. April 13, 2005); Mead v. Batchlor, 460 N.W.2d 493, 497 (Mich. 1990); Walters v. Murphy, No. 04-COA-044, 2004 WL 2757598, at *2-3 (Ohio Ct. App. Dec. 2, 2004).

56 See Dudley, supra note 34, at 1062-96. 
tions of complex labor injunctions. ${ }^{57}$ Although the opinion in that case addressed broad principles that could apply to any indirect civil contempt involving difficult fact issues, ${ }^{58}$ the Court stopped short of extending its holding beyond the context of labor injunctions. Therefore, the civilcriminal distinction remains intact outside this area.

Though the two categories of contempt are not always easy to distinguish, ${ }^{59}$ courts have come to focus on the opportunity to purge the contempt as the critical factor. ${ }^{60}$ If the contemnor has the option of ending his incarceration by compliance with an affirmative command of the court, then the sanction is regarded as civil. ${ }^{61 t t t}$

To the extent that the opportunity to purge is what distinguishes civil from criminal contempt, the reality of this opportunity is of critical importance in justifying the use of civil procedures. It is not sufficient that the purge option appear on the face of the contempt order; it must actually be possible for the contemnor to meet the purge condition and thus escape confinement. Otherwise, it is sophistic to categorize the sanction as avoidable and hence a deprivation insufficient to demand heightened due process protections against error and abuse of authority. Consequently, it has repeatedly been held that coercive imprisonment may not be imposed as a sanction for civil contempt if the contemnor lacks the ability, at the time of the contempt hearing, to purge the contempt. ${ }^{62 t t t}$

Not only is ability to comply essential to the validity of civil incarceration for contempt, it also is a necessary element for establishing the offense of contempt itself. The elements of contempt are the same regardless of whether the contempt is to be sanctioned civilly or criminally. In either case, it must be shown that the individual disobeyed a court

57 Bagwell, 512 U.S. at 836-38.

58 Id. at 831-34.

59 See, e.g., Dudley, supra note 34, at 1033.

60 The distinction between civil and criminal contempt traditionally was said to lie in the purpose and nature of the sanction imposed. Gompers v. Buck's Stove \& Range Co., 221 U.S. $418,441-42$ (1911). In regard to purpose, criminal contempt was identifiable by its motive of punishing the contemnor for disobedience of a court order, and civil contempt was identifiable by its remedial intent of coercing obedience to the order. Id. However, most contempt sanctions are motivated by mixed purposes of punishment for a prior offense and coercion of future obedience. Bagwell, 512 U.S. at 828; Hicks v. Feiock, 485 U.S. 624, 635 (1988). Consequently, the Court has long regarded purpose as an unhelpful basis for the distinction, and has instead focused more on the nature of the sanction, id. at 636, particularly the opportunity to purge the contempt.

61 Shillitani v. United States, 384 U.S. 364, 370 (1966). This is true whether the term of imprisonment absent compliance would be indefinite or fixed. Id.; Bagwell, 512 U.S. at 828.

62 Shillitani, 384 U.S. at 371; Hicks, 485 U.S. at 638 n.9; see also Young v. Fauth, 158 Md. App. 105, 114 (Md. App. 2004) (holding that purge provision based on contemnor's sale of memorabilia collection was improper, as sale of collection would take time and as a result obligor did not have ability to purge at time of contempt hearing). 
order, and that his noncompliance was willful. In other words, he must have had knowledge of the order and the ability to comply, such that his noncompliance demonstrates "contempt" of the court. ${ }^{63}$ Noncompliance by one who lacked the ability to comply is not willful and cannot support a finding of contempt.

\section{Ability to Pay, Arrearages, and the Indigent Obligor}

\section{A. Accrual of Large Arrearages by Indigents}

The federal vision of child support enforcement is in many ways a fair and efficient system for assuring that non-resident parents meet their financial support obligations. Indeed, as Legler notes, the traditional court-based system had a long record of inadequate support orders and toothless enforcement. ${ }^{64}$ The problem with the federal child support enforcement legislation is not its overall vision, its desire for efficiency, nor its creation of massive automated systems to track absent parents and seize their assets to the extent necessary to satisfy their support obligations. Rather, problems arise from the design and implementation of certain enforcement mechanisms which are ill-suited to the realities of economic life for many low-income parents.

Congress' assumptions in designing the child support enforcement statutes were based on studies indicating that most unwed fathers could pay some financial support for their children, and that their incomes tend to "rise relatively rapidly" within the few years after paternity is established. ${ }^{65}$ However, this model does not reflect the large number of noncustodial parents-particularly in families receiving welfare benefitswho are as poor as the custodial parents and have the same problems getting and keeping jobs. Welfare program administrators classify certain welfare recipients as "hard to employ" because of characteristics that make it particularly difficult to find job placements for them. ${ }^{66}$ Prominent among these characteristics, or "barriers to employment," are limited education, limited work skills, addictions, criminal records, and physical and mental health problems. ${ }^{67}$ The same barriers to employ-

63 Cf. United States v. Harrison, 188 F.3d 985, 986 (8th Cir. 1999) (stating that "willful" failure to pay child support under the federal Child Support Recovery Act "requires proof of an intentional violation of a known legal duty, and thus describes a specific intent crime.").

64 See Legler, supra note 6, at 554.

65 Id. at 527-28 \& n.47.ttt

66 See, e.g., Pamela Loprest et al., Urb. Inst., TANF Policies for the Hard to Employ: Understanding State Approaches and Future Directions (2007), available at http://www.urban.org/UploadedPDF/411501_hard_to_employ.pdf; Martha R. Burt, The "Hard to Servet": Definitions and Implications, in Welfare Reform: The Next Acr 163, 169-70 (Alan Weil \& Kenneth Finegold eds., 2002).

67 Burt, supra note 66, at 169-70. 
ment are widespread among low-income child-support obligors. ${ }^{68}$ Studies have shown that large proportions of poor non-custodial fathers lack a high-school degree or GED, ${ }^{69}$ have criminal records, ${ }^{70}$ and suffer from health conditions that limit the kind or amount of work they can perform. ${ }^{71 t t t}$

Furthermore, indigent non-custodial parents lack access to forms of government assistance available to custodial parents that help address these barriers. ${ }^{72}$ Non-custodial parents are generally ineligible for cash assistance and employment-related services available from the TANF program..$^{73}$ In addition, they have limited access to Medicaid, food stamps, and the Earned Income Tax Credit. ${ }^{74 t t}$

As a result of these and other factors, employment prospects for low-income non-custodial fathers are limited. ${ }^{75}$ One study found that fewer than one in five such fathers have full-time, year-round work. ${ }^{76}$ In 1998, low-income non-custodial fathers worked an average of 29.9 weeks per year, with 36 percent working fewer than thirty-five hours per week. ${ }^{77}$ These fathers earned an average of $\$ 4,221$ annually, compared to $\$ 34,967$ annually for non-poor non-custodial fathers. ${ }^{78}$ As noted by one researcher, the personal income of these parents "is barely enough to support themselves, making it difficult to support children living elsewhere."79ttt

Despite their economic limitations, indigent child support obligors often end up accumulating thousands of dollars in arrearages, making them prime candidates for contempt proceedings. Child support obligors

68 Elaine Sorensen \& Chava Zivman, Urb. Inst., A LoOK at PoOR Dads Who DON'T PAY CHILD SuPPORT (2000), available at http://www.urban.org/UploadedPDF/anf_b30. pdf.

69 Id. at 3; Linda Levine, The Economic Status of Noncustodial Fathers of ChilDREN ON WELFARE 4-5, 13 (2002).

70 LeVINE, supra note 69, at 4-5.

71 Id. at 9, 15; SORENSEN \& Zivman, supra note 68, at 2.

72 See id. at 8-9.

73 See id. at 10-12.

74 See id. at 7-14. This study found that, in 1996, less than 1 percent of poor nonresidential fathers received AFDC cash benefits, 6 percent received food stamps, and 25 percent received Medicaid. Id. at 9. Parents generally received these benefits on account of subsequently born children who resided in the household with the non-custodial parent. Id. In 1996, 60 percent of non-residential fathers were not covered by any form of health insurance. Id.

75 Research has established that educational attainment and unemployment are inversely related. See LEVINE, supra note 69 , at 7.

76 Elaine Sorensen, Urban Inst., Obligating Dads: Helping Low-Income NoncusTODiAl FAthers Do More FOR TheIr ChILdren 4 (1999), available at http://www.urban.org/ publications/309214.html (last visited Mar. 12, 2009).

77 LEVINE, supra note 69, at 15.

78 Id.

79 SORENSEN, supra note 76, at 4 . 
owed more than $\$ 105$ billion in 2006 in 11.1 million child support cases. $^{80}$ The percentage of non-payors was greatest in the low-income tier. ${ }^{81}$ A look at the "Most Wanted" list of any state child support agency reveals laborers, construction workers, and restaurant workers with arrearages in the tens of thousands of dollars. ${ }^{82}$ In a 2002 report, HHS's Office of the Inspector General concluded that the delinquency of 60 percent of low-income non-payors is attributable to income levels, employment history, education levels, and rate of institutionalization rather than unwillingness to pay. ${ }^{83 \mathrm{ttt}}$

\section{B.eeProblems in the Setting of Child Support Amounts for Indigentseee}

Unduly large arrearages for low-income persons have resulted botheee from systemic flaws in the child support system and from the use of processes that low-income persons don't understand and that fail to reflect the economic realities of the marketplace for unskilled labor. These phenomena cause support orders in many cases to be set at levels that exceed the obligor's economic means or fail to reflect his or her reasonable employment expectations. The problem is compounded by obstacles to modification of excessive orders.

\section{1.eeelnadequate Informationeee}

For an initial support order to "correctly" set an appropriate support amount, the court or other decision maker must have access to complete and accurate information concerning the non-custodial parent's income and any other information required by applicable child support guidelines. ${ }^{84}$ For various reasons, the court often lacks this information with

80 OCSE 2006 PRELIMINARY Report supra note 1, at 2. By way of comparison, OCSE collected $\$ 25$ billion in child support during that year. $I d$.

81 Janet Rehnquist, U.S. Dep't of Health \& Human Servs., Child support for ChildRen ON TANF 2 (2002). In 1998, about 50 percent of non-custodial parents in the child support enforcement system earned below the poverty line. Id. at $\mathrm{i}, 6$.

82 See, e.g., Mass.gov, Ten Most Wanted in Massachusetts for Failure to Pay Child Support, http://www.mass.gov/Ador/docs/cse/wanted/2007/TMW2007.pdf; Louisiana Dep't of Soc. Servs., Support Enforcement Servs. Program, Non-Custodial Parent Delinquency List, http://www.dss.louisiana.gov/Documents/OFS/AB.pdf; Va. Dep't of Soc. Servs., Child Support - Most Wanted Evaders, http://www.dss.state.va.us/family/wanted.html (last visited Mar. 12, 2009).

83 Id. at 2.

84 See generally Robert G. Williams, Guidelines for Setting Levels of Child Support Orders, 21 FAM. L.Q. 281, 290-93 (1987) (discussing information requirements for setting child support amounts). Information required by the child support formulas of some states includes, for example, the obligee's income, age of the child(ren), child care and other expenses specifically related to the child(ren), the obligor's occupation, his work related expenses, and his other dependents. $I d$. In addition, the formula incorporated in the guidelines must be one that leads to an equitable result. See infra notes 97-100 and accompanying text. 
regard to low-income parents. The parent may fail to appear, ${ }^{85}$ or the parent's evidence concerning income and employment may be incomplete or confusing, particularly if he does not have a steady job. ${ }^{86} \mathrm{Com}-$ monly, the only evidence of the indigent parent's income and assets comes from the parent's own testimony, which the court may discount as self-serving and lacking credibility. ${ }^{87}$ In these cases the amount of child support ordered may represent nothing more than an educated guess.

\section{2.eeeImputed Incomeeee}

Excessive child support awards also result from systemic flaws, such as the use of imputed income, flawed child support guidelines, and retroactive support awards. ${ }^{88}$ When the noncustodial parent fails to appear at the hearing, the court will impute an income to the parent, which then serves as the basis for the support award. ${ }^{89}$ The court will also impute income when it determines that the obligor is underemployedthat is, the court believes the obligor has an earning capacity greater than is reflected by his or her actual earnings, a belief which may or may not be accurate. ${ }^{90 t t t}$

Courts use different techniques for determining the amount of income to be imputed to the obligor. If relevant evidence is available, a court may attempt to set an income amount that accurately reflects the

85 A 2001 report by the Judicial Council of California found that courts issue 70 percent of all child support orders by default judgment. Shannon Bettis Nakabayashi, A "Dual System" of Family Law Revisited: Current Inequities in Californiats Child Support Law, 35 U.S.F. L. REv. 593, 613 (2001). A report prepared jointly by advocates for both fathers and mothers in the child support system cited the following as reasons for low-income parents' failure to appear: "Because they often do not have stable living arrangements, some may not receive notice of hearings; others may receive notice, but not understand its significance, or may be reluctant to interact with the formal legal system." NAT'L WOMEN's LAW C'TR. AND Ctr. on Fathers, Families, and Pub. Pol'y, Dollars and Sense: Improving the Determination of Child Support Obligations for Low-Income Mothers, Fathers and Children 14 (2002) [hereinafter Nat'l Women's Law Ctrk., Dollaks and Sense].

86 Nat'l Women's Law C'Tr., Dollars and Sense supra note 85, at 4.

87 See, e.g., Falkner v. Falkner, 769 So. 2d 933, 934-35 (Ala. App. 2000); In re Warner, 905 A.2d 233, 236 (D.C. 2006); Larsen v. Larsen, 949 So. 2d 278, 279 (Fla. Dist. Ct. App. 2007); Stuber v. Stuber, No. 1-02-65, 2003 WL 1826294, at *5 (Ohio Ct. App. Apr. 9, 2003); Phillips v. Knox, No. E2000-02988-COA-R3-JV, 2001 WL 1523347, at *8 (Tenn. Ct. App. Nov. 29, 2001); DHS v. Rhea, No. E2005-00330-COA-R3-JV, 2006 WL 770518, at *4 (Tenn. Ct. App. Apr. 23, 1993); Ex parte Garrison, 853 S.W.2d 784, 787-88 (Tex. App. 1993).

88 Jessica Pearson \& Esther Ann Griswold, New Approaches to Child Support Arrears, Pol'y \& Prac. of Pub. Human Servs., Sept. 1, 200t, at 33, available at http://www.ancpr. org/new_approaches_to_child_support_htm (last visited Mar. 12, 2009).

89 Id.

90 See, e.g., In re Marriage of Fogle, 497 N.W.2d 487, 488-89 (Iowa Ct. App. 1993) (finding that individual who had been unemployed for 3.5 years and whom the trial court described as an "ignorant, dull-witted, lazy, inarticulate, unmotivated, thick-headed moron of a man" had capacity to get a forty-hour per week minimum wage job). 
obligor's earning potential. ${ }^{91}$ In the absence of such evidence, the court may impute to the obligor the ability to earn the minimum wage, ${ }^{92}$ or it may simply take a stab in the dark. ${ }^{93}$ Regardless of the technique used, the court generally assumes a forty-hour work week. ${ }^{94}$ Imputation of income frequently overestimates the income of low-income parents, who often work less than a forty-hour week, may receive less than minimum wage, and frequently work sporadically. ${ }^{95 t t t}$

\section{3.eeeMinimum Awardseee}

The child support guidelines of some states incorporate other devices that routinely result in excessive awards against low-income parents. More than half the states have a minimum child support award, which in 1999 ranged from $\$ 20$ per month to $\$ 179$ per month. ${ }^{96}$ The most common minimum award was $\$ 50$ per month. ${ }^{97}$ Child support at this minimum amount may be ordered regardless of the actual income or employment prospects of the obligor, on the theory that all parents, re-

91 See Quance v. Quance, No. C3-00-692, 2001 WL 32802, at*4 (Minn. Ct. App. Jan. $16,2001)$ (requiring information about obligor's earnings history and current availability of jobs; if obligor is self-employed, court requires information about obligor's present ability to generate income from self-employment at the historical level); Rebecca Sue A. v. Joseph A., No. OT-99-076, 2000 WL 770137, at *2 (Ohio Ct. App. June 16, 2000) (requiring expert testimony regarding the average hourly wage for plumbers, current job openings in the area for plumbers of obligor's skill level, and how much these openings would pay).

92 See, e.g., In re A.P., 46 S.W.3d 347, 349 (Tex. App. 2001). A presumption to this effect may be created by statute. See Tex. FAM. ConE Ann. § 154.068 (2002). In Marriage of Fogle, the court imputed to father the ability to get a full-time job paying minimum wage, even though he was unemployed and trial court found him to be an "ignorant, dull-witted, lazy, inarticulate, unmotivated, thick-headed, moron of a man." See Marriage of Fogle, 497 N.W.2d at 488.

93 See Michael F. v. Sharon R., No. OT-00-034, 2001 WL 227068, at *2 (Ohio Ct. App. 2001) (finding that the court may exercise broad discretion when imputing income).

94 Pearson \& Griswold, supra note 88 , at 33.

95 A 1998 study in the state of Iowa found that imputing income on the basis of median household income resulted in orders averaging $\$ 383$, as compared to a $\$ 250$ average for orders based on individualized income data. Iowa Dep't of Human Servs., Three Child Support Recovery Issues: Income Withholding Arrearage Rates, Accrued Support Debt Owed to the Staie, Alternatives to Median Income (1998). This report is discussed in Pearson \& Griswold, supra note 88, at 34.

96 June Gibbs Brown, U.S. Dep’t of Health \& Human Servs., State Policies Used to Establish Child Support Orders for Low Income Non-custodial Parents 20-22 (2000) [hereinafter U.S. Dep't of Health \& Human Servs., State Policies Report]. Under Federal law, the specified minimum award cannot be mandatory; it can only be a rebuttable presumption. 42 U.S.C. $\$ 667$ (b)(2) (2000). However, the rebuttal grounds set forth in state guidelines are generally narrow and unrelated to income deficiencies. For example, the Ohio guidelines permit the court to award less than the $\$ 50$ minimum only upon proof of the obligor's "medically verified or documented physical . . . disability or institutionalization in a facility for persons with a mental illness or any other circumstances considered appropriate by the court." Ohio Rev. Code Ann. § 3119.06 (West 2003).

97 U.S. Dep't of Health \& Human Servs., State Policies Report, supra note 96, at 20-22.ttt 
gardless of income, should make some financial contribution to their child. ${ }^{98}$ Consequently, the minimum award may result in a child support obligation that constitutes a disproportionate share of, or even exceeds, the indigent obligor's income. ${ }^{99 t t t}$

\section{4.eeeRetroactive Awardseee}

A retroactive support award treats the accrual of child support as commencing at some time prior to entry of the order. For divorced or cohabiting parents, this date is generally the date when the parties separated. ${ }^{100}$ For other nonmarital parents, the accrual of child support mayeee begin upon the birth of the child. ${ }^{101}$ Retroactive awards are based on theee parent's legal obligation to support his or her child from the time of the child's birth. Failure to support the child at any time, whether or not an order is in place, constitutes a legal default subject to later enforcement by the courts. ${ }^{102}$ Particularly in the case of nonmarital fathers, whoseeee paternity may not be definitively established until the child support proceeding, the retroactive award may extend over a period of years, ${ }^{103}$ re-

98 Id. at 17.

99 A recent study of California child support obligors found that the lowest income group had orders requiring payment of \$2.11 per dollar earned. See Michelle Ganow Jones, Options to Help Low-Income Noncustodial Parents Manage Their Child Support Debt, 6 Welfare INFORMATION NeTwORK: Issue Notes, Oct. 2002, at 5, available at http://www.financeproject info.org/Publications/optionstohelplowincomeIN.htm (last visited Mar. 12, 2009). Orders of this magnitude are possible not only because of problems in the original support-setting process, but also because arrearages, interest on arrearages, and attorney fees to parties initiating enforcement proceedings can be added to the original support amount. See 42 U.S.C. $\$ \mathrm{t666(c)(1)(H)} \mathrm{(regarding} \mathrm{arrearages);} \mathrm{Miller} \mathrm{v.} \mathrm{Kelk,} \mathrm{No.} \mathrm{E2003-02180-COA-R3-JV,} \mathrm{2005ttt}$ WL 1669849, at $* 8$ (Tenn. Ct. App. July 18, 2005) (awarding custodial parent $\$ 1,500$ in attorney fees). Some states charge up to 12 percent interest on unpaid child support, substantiallyttt increasing the amount owed. MAY \& Roulet, supra note 13, at 9, 14; see also, e.g., Falknerttt v.ttFalkner, 769 So. 2d 933, 934 (Ala. App. 2000) (finding that obligor had arrearage ofttt $\$ 5,232.40$, plus interest of \$942.70); Vitt v. Rodriguez, 960 So.2d 47, 48 (Fla. Dist. Ct. App.ttt 2007) (stating that entitlement to interest in child support context is well established in Floridattt law); Smith v. Smith, No. 2007AP1220-FT, 2007 WL 2442334, at*1 (Wis. Ct. App. Apr. 30,ttt 2007) (finding that obligor owed $\$ 13,753.64$ in arrears plus interest of $\$ 18,466.31$ ). In thesettt states, courts may apply partial payments first to interest, leaving the arrearage intact to continue accumulating interest. See Vitt, 960 So.2d at 48. But see T.L.D. v. C.G., 849 So.2d 200,ttt 204 (Ala. Civ. App. 2002).ttt

100 See, e.g., Miller v. Kelk, No. E2003-02180-COA-R3-JV, 2005 WL 1669849, at *4-5 (Tenn. Ct. App. 2005) (finding abuse of discretion in trial court's failure to award retroactive support).

101 See, e.g., People ex rel B.W., 17 P.3d 199,t20t (Colo. Ct. App. 2000); In re Hope, No. 98-1004, 1999 WL 668715, at $* 2$ (Iowa Ct. App. Aug. 27, 1999).tt

102 See, B.tW, 17 P.3d at 201.ttt

103 Maureen Waller \& Robert Plotnick, Child Support and Low-Income Families: Percepitions, Practices, and Policy 39 (1999); U.S. Dep't of Health \& Human Servs., State Policies Report, supra note 96, at 6-10; Pearson \& Griswold, supra note 88, at 34 . In some jurisdictions a retroactive award for the full eighteen years of the child's minor-

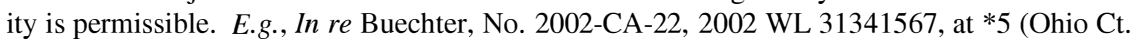
App. Oct. 18, 2002); In re A.P., 46 S.W.3d 347, 349 (Tex. App. 2001) (holding that a statute 
sulting in retroactive awards in the thousands of dollars. ${ }^{104}$ Some states add costs associated with the birth of the child and possibly a variety of fees as well. ${ }^{105}$ From the moment such an order is entered, the obligor is subject to substantial arrearages in addition to the current support obligation. Thus, low-income obligors, who generally lack the assets to pay a large retroactive award, enter a state of permanent arrearage. ${ }^{106}$

Courts generally deal with arrearages by adding to the "current" monthly support obligation an additional amount to be applied toward arrearages. Even when the award of current support accurately reflects the amount of support the obligor could afford to pay, the addition of an arrearage component will inherently cause the award to exceed the obligor's ability. ${ }^{107}$

\section{Non-Traditional Wage Trajectories}

More fundamentally, child support guidelines are designed for situations in which it is possible to project an amount that the parent can reasonably be expected to pay each month over an extended period of time. ${ }^{108}$ The prototypical case would be one in which the obligor has stable employment with a constant, if not upward, ${ }^{109}$ wage trajectory. ${ }^{110 t t t}$ For many low-income persons, however, their job trajectory lacks this kind of consistency. ${ }^{111}$ Employment is sporadic, with wages fluctuating from one job to the next and separated by periods of unemployment, thus causing frequent changes in the obligor's ability to pay. ${ }^{112}$ Because of

mandates retroactive support). In others, the number of years may be limited by a statute of limitations, see Clough v. Balliet, No. 98-009196, 2001 WL 1654952, at*1 (Mich. Ct. App. Dec. 21, 2001), or by a requirement such as notice of the claim of paternity. See State ex rel. Schaaf v. Jones, 515 N.W.2d 568, 570-71 (Iowa Ct. App. 1994); Buechter, 2002 WL 31341567 at $* 5$.

104 See, e.g., Hope, $1999 \mathrm{WL} 668715$ at *3 (awarding retroactive child support of $\$ 20,000$ ); Young v. Fauth, 854 A.2d 293, 295 (Md. App. 2004) (enforcing retroactive award of \$8,828); Buechter, 2002 WL 31341567 at *11 (awarding \$23,274.39 retroactively).ttt

105 See U.S. Dep't of Health \& Human Servs., State Policies Report, supra note 96, at $10-12$.

106 See WALlER \& Plotnick, supra note 103, at viii.

107 See id.

108 See id. at 3.

109 The federal provision for triennial modification without changed circumstances, though neutral on its face, was intended to provide an opportunity for increasing support awards that were inadequate or had become (inadequate) due to inflation or the obligor's job advancement. See Legler, supra note 6, at 559-60 \& n. 212-13.

110 See Waller \& Plotnick, supra note 103, at ix-x.

111 See id. at 3.

112 See id. at 37-38; Elaine Sorenson \& Helen Oliver, Urban Inst., Child Support REFORMS IN PRWORA: INITIAL IMPACTS 11 (2002), available at http://www.urban.org/url.cfm ?ID=410421 (last visited Mar. 12, 2009) (listing other barriers to support for low-income noncustodial parents); Elaine Sorenson \& Helen Oliver, Urban Inst., Child Support Reforms Are Needed to Increase Child Support from Poor Fathers 7 (2002) [hereinafter Sorenson \& Oliver, PoOr FAthers], available at http://www.urban.org/UploadedPDF/410 
the unpredictability of the obligor's ability to generate income on a regular monthly basis, the likelihood of inappropriate awards is particularly high. $e^{13}$

\section{C.eedimitations on Modification of Support Awardseee}

Mechanisms exist for modifying child support awards. However,eee limitations on the circumstances in which modification is available, judicial and administrative hostility to downward modification, and barriers affecting access to modification procedures limit the utility of modification as a source of relief for the low-income obligor subject to an excessive support award.

Federal law requires review and adjustment of support orders every three years at the request of either parent. ${ }^{114}$ However, most states will adjust the support amount only if the change exceeds a specified threshold-either a percentage of the existing award or a monetary amount. ${ }^{115}$ The monetary thresholds, requiring a change in the monthly award ranging from $\$ 10$ to $\$ 100, e^{16}$ present a particular obstacle for indigent obligors. Changes in their already low incomes may not be sufficient to support a decrease in the award that exceeds the threshold amount. Furthermore, the three-year interval does not provide the flexibility needed to respond meaningfully to the unstable economic situation of many lowincome obligors.

Both common law and federal statute also provide for modification of child support orders at any time upon a showing of changed circumstances.e ${ }^{17}$ Again, however, states have limited the availability of the modification remedy by restricting the types of changes that warrant an adjustment in the support amount. ${ }^{118}$ In all jurisdictions, the change must be "substantial," a requirement that generally translates into a quan-

477.pdf (finding that in 1999, only 34 percent of non-incarcerated poor fathers worked fulltime, and only eight percent worked full-time, full-year).ttt

113 It is theoretically possible that income could be either higher or lower than projected. In reality, however, the projection almost always overestimates income because it is generally based on an assumption of full-time employment. See Legler, supra note 6, at 558 n.210. Studies have found that the child support obligations of low-income parents of ten represent an unreasonably high proportion of their earnings, REHNQUIST, supra note 81 , at 7; SORENSON \& Oliver, PoOR FAthers, supra note 112, at 5 (making non-payment and accumulation of arrearages almost inevitable).

11442 U.S.C. $\$ 666(\mathrm{a})(10)(\mathrm{A})(2000)$.

115 See June Gibbs Brown, U.S. Dep't. of Healih \& Human Servis., Review and Aduustment of Support Orders 6 (1999); State DHS v. Rhea, No. E2005-00330-COA-R3JV, 2006 WL 7705t 8, at *5 (Tenn. Ct. App. Mar. 27, 2006) (refusing modification because of failure to meet 15 percent threshold).

116 See Brown, supra note 115 , at 6 .

11742 U.S.C. § 666(a)(10)(B).

118 See Brown, supra note 115, at 6. 
titative variance between the existing and adjusted amounts similar to the "threshold amount" requirement discussed above. ${ }^{119}$

Some states impose other limitations that further restrict the availability of "changed circumstances" modification. Some states hold that only changes that were unforeseeable at the time of the original order can serve as grounds for modification. ${ }^{120}$ This requirement affects most cases involving employment instability, which for low-income obligors is generally foreseeable. Another common requirement demands that the change be involuntary and in good faith. Quitting a job is likely to be viewed as voluntary, regardless of motivation or rationale, ${ }^{121}$ as is termination attributable to the employee's malfeasance. ${ }^{122}$ Continued unemployment is considered voluntary if the obligor has failed to make sufficient efforts to find employment. ${ }^{123}$ Some courts also view imprisonment as voluntary, based on the voluntariness of the underlying criminal act. ${ }^{124 t t t}$

In addition to these obstacles inherent in the support modification process, the indigent obligor seeking relief faces a widespread hostility to downward modification of child support obligations. ${ }^{125}$ At the administrative level this hostility may be embodied in policies providing less favorable treatment for non-custodial parents seeking downward adjustment or even barring downward adjustment altogether. ${ }^{126}$ At least one state allows only non-custodial parents without arrears to have their orders reviewed or adjusted. ${ }^{127}$ Further, a study by the HHS Inspector General found that even in the absence of a stated policy disfavoring non-custodial parents, local administrators may nonetheless deny noncustodial parents the opportunity for review and adjustment. ${ }^{128 t t t}$

119 Nat'l Women's Law CTr., Dollars and Sense, supra note 85, at 22.

120 See, e.g., Robinson v. Robinson, 928 So. 2d 360, 363 (Fla. Ct. Dist. App. 2006).

121 See, e.g., State ex rel Phillips v. Knox, No. E2000-02988-COA-R3-JV, 2001 WL 1523347, at*5 (Tenn. Ct. App. Nov. 29, 2001).

122 See, e.g., In re Marriage of Hester, 565 N.W.2d 351, 354 (Iowa Ct. App. 1997); In re Rossino, 899 A.2d 233, 236 (N.H. 2006); Edwards v. Lowry, 348 S.E.2d 259, 261 (Va. 1986).

123 E.g., In re Warner, 905 A.2d 233, 235 (D.C. 2006); Bowen v. Bowen, 471 So. 2d 1274, 1276 (Fla. 1985).

124 E.g., Mascola v. Lusskin, 727 So. 2d 328, 332 (Fla. Dist. Ct. App. 1999); Koch v. Williams, 456 N.W.2d 299, 301 (N.D. 1990); Rhodes v. Rhodes, No. 00 BA 34, 2001 WL 1199877, at *3 (Ohio Ct. App. Sept. 25, 2001).

125 See, e.g., Brown, supra note 115, at 9-10; Paula Roberts, An Ounce of Prevention and a Pound of Cure: Developing Staie Policy on ihe Payment of Child Suppori Arrears by Low Income Parents 12-13 (2001).

126 See Brown, supra note 115, at 9-10; see also ROBERTs, supra note 125 , at 12-13 (describing the limited circumstances when low-income parents could have their custodial obligations adjusted downward or eliminated entirely).

127 Brown, supra note 115 , at 9.

128 Id. at 10. Several workers stated that they feel "their responsibility is to custodial parents and their children rather than to non-custodial parents." Id. 
Courts, too, exhibit a disinclination to make downward adjustments in child support awards. $e^{29}$ In cases where obligors are able to establish job loss or other substantial change affecting earnings, the courts typically impute income based on a finding of voluntariness, rather than adjusting the award to reflect actual income. ${ }^{130}$ Determinations that a job loss was voluntary, ${ }^{131}$ that an obligor has failed to make adequate efforts to find a new job, ${ }^{132}$ or that an obligor could be earning more than is paid by his current employment ${ }^{133}$ involve assessments of motive and credibility, value judgments about how much effort is enough, and suppositions about what might have been. All of these leave significant room for judicial values, assumptions, and attitudes to affect the outcome.

Finally, most low-income obligors simply lack meaningful access to processes for obtaining modification. ${ }^{134}$ Low-income obligors have limited understanding of their legal rights, ${ }^{135}$ do not know how to access the legal system or present their case effectively, and are intimidated by courts and other official fora. ${ }^{136}$ They also lack the funds to hire legal counsel to help them navigate the system, and no jurisdiction recognizes a right to appointed counsel in proceedings to establish or modify the child support amount. ${ }^{137}$ These difficulties were acknowledged by one judge, who stated:

[If] the contemnor is not well-educated and has not had the continuous assistance of counsel, I do not believe that he or she should face incarceration for criminal contempt simply because he or she failed to take measures to seek reduction of his or her child support obligation,

129 See, e.g., T.L.D. v. C.G., 849 So.2d 200 (Ala. Civ. App. 2002); Herrera v. Sanchez, 885 So.2d 480, 481 (Fla. App. 2004).

1 t30 E.g., T.L.D., 849 So.2d 200; Dorner v. McCarroll, 271 A.D.2d 530 (N.Y. App. Div. 2000); Phillips v. Knox, No. E2000-02988-COA-R3-JV, 2001 WL 1523347 (Tenn. Ct. App. Nov. 29, 2001).

131 See, e.g., T.L.D., 849 So.2d 200.

132 See, e.g., Phillips, 2001 WL 1523347.

133 See, e.g., Dorner, 271 A.D.2d 530.

134 See, e.g., Herrera, 885 So.2d at 481 (holding that an indigent father who twice attempted to initiate downward modification of support, with no hearing ever held, was in contempt for nonpayment). A study by the DHHS Inspector General found that "the overwhelming majority of requests for review come from parents on non-public assistance cases." BROWN, supra note 115 , at 7.

135 Nat'l Women's Law CTr., Dollars and Sense, supra note 85, at 23 (“[M]any lowincome parents do not know of their rights to seek a review and adjustment."); see also BROWN, supra note 115, at 7 (expressing concerns about adequacy of notice to parents of right to request review).

136 See, e.g., Leslie Kaufman, Tough Child Support Laws Put Poor Fathers in a Bind, N.Y. Times, Feb. 19, 2005, at B1, B4 (describing the myriad challenges for a homeless man to pay child support).

137 See, e.g., Tetro v. Tetro, 544 P.2d 17, 19-20 (Wash. 1975) (holding that there exists no right to counsel in child support proceedings). 
even if the necessity of such measures would. doubtless seem obvious to a competent attorney. ${ }^{138}$

In any event, it is too late at the point of modification to affect arrearages that have already accumulated as a result of excessive awards, as federal law prohibits retroactive modification of accrued child support. ${ }^{139}$ The federal prohibition on retroactive modification, often referred to as the "Bradley Amendment," was aimed at preventing "the practice of a noncustodial parent moving to another State, allowing a substantial debt to his or her child to pile up, and assuming that there will be a retroactive modification of the original order that substantially reduces or totally dismisses the debt." 140 The only exception to the prohibition applies to periods when a petition for modification is pending. ${ }^{141 t t t}$

The Bradley Amendment, like so many aspects of child support law, addressed a legitimate problem - the willingness of judges to reduce child support debt despite the legitimacy of the award and the obligor's ability to pay - with a broad prohibition that also encompasses situations in which retroactive modification would not implicate these concerns. ${ }^{142 \mathrm{ttt}}$ In cases with which this Article is concerned, for instance, the prohibition prevents relief to those whose award was initially set inappropriately high, those who did not seek a modification immediately upon a reduction in income or other change of circumstances, and others with legitimate justifications for nonpayment of some or all of the support award. The prohibition on retroactive modification removes the final safety net for the indigent obligor who has amassed huge arrearages because of failures in the system and his own lack of legal sophistication.

\section{Arrearages and Civil Contempt}

A system in which child support awards are commonly set beyond the parent's ability to pay, modification procedures are neither realistically available nor likely to address inequities, and retroactive correction is disallowed, inevitably results in the accrual by many parents of large and unpayable arrearages. Eventually, many of these parents face charges of contempt of court for their failure to pay the court-ordered support.

138 In re Warner, 905 A.2d 233, 248 n.11 (D.C. 2006) (Schwelb, S.J., concurring).

13942 U.S.C. \$666(a)(9) (2000). In addition to prohibiting retroactive modification, the Bradley Amendment required state laws to make unpaid child support a judgment by operation of law, entitled to full faith and credit in every state. Pub. L. No. 99-509, §9103, 100 Stat. 1874 (1986) (codified at 42 U.S.C. \$666(a)(9)).

140132 Cong. Rec. S5303-04 (daily ed. May 5, 1986) (statement of Sen. Bill Bradley).

14142 U.S.C. § 666(a)(9) (2000).

$142 I d$. 
Faithful adherence to the laws limiting the contempt power would bar its application in these circumstances. A nonpaying obligor is in contempt of court only if his or her noncompliance was willful-that is, the obligor had both knowledge of the order and the ability to comply. ${ }^{143}$ Furthermore, coercive imprisonment is permissible as a sanction for civil contempt only if the contemnor has the present-at the time of sanctioning - ability to pay either the full amount of the arrearage or a lesser sum set by the court as the amount necessary to purge the contempt. ${ }^{144}$ Otherwise, no coercive potential exists ${ }^{145}$ and imprisonment becomes merely punitive in nature, thus demanding criminal procedural protections in order to satisfy due process. ${ }^{146}$ Thus, ability to comply is a key issue in contempt proceedings based on noncompliance with a child support order, both in establishing the contempt ${ }^{147}$ and in justifying the sanction of coercive incarceration. ${ }^{148 t t t}$

A low-income obligor may not have had the ability to make the ongoing support payments, in which case he or she was not in contempt at all. ${ }^{149}$ Or if in contempt, the low-income obligor is rarely a candidate for civil incarceration because of the likelihood that he or she is unable to pay the hefty sum represented by the accumulated arrearages, or even a portion thereof that may be set by the court as the purge amount. ${ }^{150}$

\section{A. Extent of Incarceration of Indigents}

The inability of indigent obligors to make court-ordered payments or to pay purge amounts would not be a systemic legal problem if courts were not finding such obligors in contempt and then coercively imprisoning them despite their inability to pay. There is little hard data to show the number of indigent child support obligors who are jailed for nonpay-

143 E.g., Rinehart v. Nowlin, 805 P.2d 88, 95 (N.M. App. 1990); cf. United States v. Harrison, 188 F.3d 985, 986 (8th Cir. 1999) (noting that the "willful" failure to pay child support under federal Child Support Recovery Act "requires proof of an intentional violation of a known legal duty, and thus describes a specific intent crime").

144 See United States v. Rylander, 460 U.S. 752, 757 (1983).

145 Harrison, 188 F.3d 986.

146 See Puchner v. Kruzicki, 918 F. Supp. 1271, 1278 (E.D. Wis. 1996); In re Feiock, 263 Cal. Rptr. 437, 440 (Cal. Ct. App. 1989) (citing Hicks v. Feiock, 485 U.S. 624, 638-40 (1988)); Bresch v. Henderson, 761 So.2d 449, 450-51 (Fla. Dist. Ct. App. 2000); Brittania Holdings Ltd v. Greer, 113 P.3d 1041, 1044 (Wash. Ct. App. 2005).

1.47 See, e.g., Herold v. Herold, No. 04AP-206, 2004 WL 2895792, at*7-8 (Ohio Ct. App. Dec. 14, 2004) (holding that the trial court abused its discretion in finding defendant in contempt where, during the compliance period at issue, "through no fault of her own, defendant financially was unable to comply with the court's order").

148 Ex parte Rojo, 925 S.W.2d 654, 656 (Tex. 1996).

149 See, e.g., Herold, 2004 WL 2895792 at *7-8.

150 E.g., In re Gawerc, 165 S.W.3d 314, 315 (Tex. 2005). 
ment, nor even the total number of child support contemnors. ${ }^{151}$ However, the limited existing data suggest that the number is substantial:

•e When a 2003 New Jersey Supreme Court ruling mandated the release of all indigent child support contemnors who had not beene represented by counsel, experts estimated that 300 persons woulde be released. ${ }^{152 t}$

-e The Delaware Supreme Court found that in that state the Familye Court sentenced 518 civil contemnors to a period of incarceratione in $1995 .{ }^{153 t}$

- A 1982-1983 study found that during a two-year period, 131 civile contemnors were jailed for nonpayment of child support in a single New Mexico county. ${ }^{154 t}$

- An Indiana child support prosecutor reported in 2002 thate 2,400-3,300 child support obligors were incarcerated annually fore nonpayment, $80-85$ percent of them for civil contempt. ${ }^{155 t}$

- A 2005 survey of South Carolina jails revealed that the state'se jails averaged over 1,500 child support contemnors at any givene time. ${ }^{156 t}$

- A report by the Center for Family Policy and Practice summarizese numerous newspaper and other reports from thirty-six states documenting widespread arrests and incarcerations of nonpayinge obligors. ${ }^{157 \mathrm{t}}$

The demographics of child support caseloads, particularly those with significant arrearages, support the conclusion that a substantial majority of these contemnors are indigent or otherwise without the means to pay the purge amount. According to the federal Office of Child Support Enforcement, in 2006 over $\$ 105$ billion in arrearages were owed by 11.1

151 See generally MAY \& Roulet, supra note 13, at 11-12 (describing the limited statistical information available pertaining to the number of arrests of child support obligors who do not pay child support).

152 Id. at 29.

153 Black v. Div. of Child Support Enforcement, 686 A.2d 164, 167 n.4 (Del. 1996).

154 Michele Hermann \& Shannon Donahue, Fathers Behind Bars: The Right to Counsel in Civil Contempt Proceedings, 14 N.M. L. Rev. 275, 277 (1984).

155 May \& Roulet, supra note 13, at 20 (citing Ind. Child Custody and Support Advisory Comm., Meeting Minutes, Sept. 30, 2002, http://www.in.gov/legislative/interim/committee/2002/committees/minutes/CCSA59U.pdf).

156 Elizabeth G. Patterson, Child Support Detainees by County 2009 (on file with author).

157 MAY \& RoulET, supra note 13, at 13-38. These researchers found that reporting on officials responsible for aggressive programs of arresting parents who are behind in their child support often "represent [the officials'] efforts as being targeted only at those 'deadbeat' parents who can afford to pay but don't. In fact, however, the same [reporting] often includes information that belies this characterization ...." Id. at 12 . 
million obligors. ${ }^{158}$ The majority of the obligors with arrearages, and thus subject to repeated contempt proceedings, are below the poverty line. ${ }^{159}$ The federal Office of Child Support Enforcement reports that 70 percent of child support arrearages are owed by noncustodial parents with no annual earnings or earnings less than $\$ 10,000 .{ }^{160}$ Only 4 percent are owed by non-custodial parents with an annual income of $\$ 40,000$ or more. ${ }^{161 t}$

The contempt process is used only with those contemnors from whom support cannot be obtained through other enforcement techniques, including wage withholding and seizure of assets. ${ }^{162}$ Non-indigent obligors against whom it is necessary to institute contempt proceedings generally pay the arrearage when threatened with jail. It can reasonably be inferred, therefore, that when large numbers of child support obligors are incarcerated, most are indigent.

This conclusion is further buffered by the facts of appellate cases from throughout the nation that show indigent obligors being jailed for civil contempt with little attention to the economic circumstances underlying their noncompliance. ${ }^{163}$ Indigents are especially unlikely to appeal civil contempt orders, given their lack of access to appellate counsel in most states and the brevity of the typical contempt sentence. ${ }^{164}$ Therefore, the reported cases can be seen as indicators of a much larger number of unappealed contempt incarcerations.

158 OCSE 2006 PReliminary Report, supra note 1. In that year only \$7 billion of the outstanding arrearages were collected. Id.

159 See Office of Child Support Enforcement, The Story Behind The Numbers Understanding and Managing Child Support Debt, 1 (2008) [hereinafter OCSE Story], available at http://www.acf.hhs.gov/programs/cse/pol/IM/2008/im-08-05a.pdf (reporting obligors with no or little reported income held most of the arrears).

160 Id.

$161 \mathrm{Id}$.

162 See supra notes 15-27 and accompanying text.

163 Peterson v. Roden, 949 So. 2d 948 (Ala. Civ. App. 2006); Taylor v. Johnson, 764 So. 2d 1281 (Ala. Civ. App. 2000); Blackwell v. Nowakowski, No. FA000121344, 2005 WL 185414 (Conn. Super. Ct. May 27, 2005); In re Warner, 905 A.2d 233 (D.C. 2006); In re N.V., 890 So. 2d 1232 (Fla. Dist. Ct. App. 2005); Marks v. Tolliver, 839 N.E.2d 703, 707 (Ind.t Ct. App. 2005); Arrington v. Dep't Of Human Res., 935 A.2d 432 (Md. 2007); Long v. State,t 807 A.2d 1 (Md. 2002); Herold v. Herold, No. 04AP-206, 2004 WL 2895792 (Ohio Ct. App.t Dec. 14, 2004); State ex rel Phillips v. Knox, No. E2000-02988-COA-R3-JV, 2001 WL 1523347 (Tenn. Ct. App. Nov. 29, 2001); Zinnecker v. Sarver, 710 N.W.2d 726 (Wis. Ct. App. 2006); see also McBride v. McBride, 431 S.E.2d 14, 19 n.4 (N.C. 1993) (noting that examination of appellate cases in North Carolina indicates that failure of trial courts to make a determination of a contemnor's ability to comply with purge "is not altogether infrequent").t

164 See, e.g., Carroll County Bureau of Support v. Brill, No. 05 CA 818, 2005 WL 3489763 (Ohio Ct. App. Dec. 15, 2005) (finding appeal moot because sentence had already been completed); Evans v. Evans, No. 04AP-816, 2005 WL 2364976 (Ohio Ct. App. Sept. 27, 2005) (finding appeal moot because sentence had already been completed). 


\section{B.e The Heavy Burden of Proving Inability to Paye}

There are a number of interrelated reasons why courts incarceratee substantial numbers of indigent obligors for civil contempt despite their inability to pay the ordered support or the purge amount. Particularly important is the lack of hard evidence on issues related to the obligor's inability to pay, combined with the unfavorable structuring of the burden of proof and a judicial disinclination to find obligors' testimony credible.

In civil contempt proceedings, unlike those for criminal contempt, ${ }^{165}$ absence of willfulness is treated as a defense, and the initial burden is on the contemnor to plead and present evidence of his or her inability to comply with the order. ${ }^{166}$ Some states shift the burden back to the petitioner once the alleged contemnor makes a prima facie showing of inability to comply, ${ }^{167}$ but others place the full burden of proof in regard to willfulness/inability to comply on the defendant. ${ }^{168 t}$

Proving inability to comply can be factually complex, implicating the economic circumstances of the obligor, his work history and potential, his available assets, ${ }^{169}$ and his own subsistence needs. ${ }^{170}$ To meet

165 In criminal contempt proceedings the state is constitutionally required to prove every element of the offense beyond a reasonable doubt, including willfulness (ability to comply with the order). Hicks v. Feiock, 485 U.S. 624,t637 (1987). But see In re Warner, 905 A.2d 233 (D.C. 2006) (placing burden of proving inability to pay on obligor in criminal contempt proceeding).

166 Civil contempt proceedings are not subject to the "reasonable doubt" requirement. Hicks v. Feiock, 485 U.S. 624, 638 (1987). Hence, courts presume that a court order imports a finding of the court that the defendant has the ability to comply. Stuber v. Stuber, No. 1-0265, 2003 WL 1826294 (Ohio Ct. App. Apr. 9, 2003); Britannia Holdings Ltd. v. Greer, 113 P.3d 1041, 1045 (Wash. Ct. App. 2005). Most courts thus limit the petitioner's burden to proving the alleged contemnor's violation of the court order-generally by clear and convincing evidence. See, e.g., Rawlings v. Rawlings, 766 A.2d 98, 101 n.l (Md. 2001) (citing MD.t Rule 15-207(e)); Stuber, 2003 WL 1826294 at *4. The burden then shifts to the defendant to prove the defense of inability to comply. E.g., Herrera v. Sanchez, 885 So. 2d 480, 481 (Fla. Dist. Ct. App. 2004); Lyons v. Sloop, 40 S.W.3d 1, 10-11 (Mo. Ct. App. 2001). In regard tot ability to pay the purge, the petitioner does not have the benefit of a presumption and thus hast the burden of proving ability to pay. See, e.g., Bowen v. Bowen, 471 So. 2d 1274, 1278-79t (Fla. 1985).

167 E.g., Falkner v. Falkner, 769 So. 2d 933, 935 (Ala. Civ. App. 2000); State ex. rel. Moore v. Owens, No. 89-170-11, 1990 WL 8624, at *3 (Ten. Ct. App. Feb. 7, 1990).

168 E.g., Rawlings, 766 A.2d at $101 \mathrm{n} .1$ (explaining that alleged contemnor must prove he or she made reasonable efforts to become or remain employed or otherwise lawfully obtain funds necessary to make payment); Lyons, 40 S.W.3d at 10-11 (explaining that alleged contemnor must prove that inability to pay is not consequence of his own intentional and contumacious conduct); Stuber, 2003 WL 1826294 at *4 (stating that defendant must show inability to pay to be real and not self-imposed, nor due to fraud, sharp practices, or intentional avoidance).

169 See, e.g., In re Gawerc, 165 S.W.3d 314, 315 (Tex. 2005).

170 See, e.g., Bryant v. Howard County Dep't of Soc. Servs., No. 93, 2005 WL 1115229 (Md. App. 2005); Rodriguez v. Eighth Judicial Dist., 102 P.3d 41 (Nev. 2004); Patterson v. Patterson, No. 86282, 2005 WL 2471012 (Ohio Ct. App. Oct. 6, 2005); cf. United States v. Kukafka, 478 F.3d 531 (3d Cir. 2007) (discussing federal criminal prosecution). The amount 
this burden, the alleged contemnor must at the very least present evidence of his or her employment (or lack thereof), wages, expenses, and assets.

However, gauging the ability to pay may be much more complicated than this, involving issues of good faith responsibility for other obligations, $\mathrm{e}^{71}$ voluntariness of the obligor's unemployment or underemployment, ${ }^{172}$ and the availability of borrowed funds ${ }^{173}$ or assetse

of the original child support ordered reflects the amount that the court believed necessary to meet the needs of the obligor, and the reasoning and conclusions of the court making the award are not subject to reconsideration in a contempt proceeding. United States v. Rylander, 460 U.S. 752, 756 (1983). Nor can the order be modified in such a way as to excuse some or all of the accrued child support obligation, even if the obligor's circumstances changed after the child support award was made. However, a change in the obligor's circumstances after the award can be the basis for a finding that, at the time of the alleged contumacious act, the obligor lacked the ability to comply and hence his failure to do so was not willful.

171 The obligor may have dependents other than the child or children for whose benefit the order was entered. See, e.g., Larsen v. Larsen, 949 So. $2 d 278$ (Fla. Dist. Ct. App. 2007); Rodriguez, 102 P.3d at 44; Patterson, 2005 WL 2471012 at $* 1$. It is not uncommon for an indigent child support obligor to have fathered multiple children by different mothers, and consequently to be subject to multiple child support orders. See, e.g., Davison v. Miss. Dep't of Hum. Servs., 938 So. 2d 912 (Miss. App. 2006); Herold v. Herold, No. 04AP-206, 2004 WL 2895792, at *7 (Ohio Ct. App. Dec. 14, 2004); Zinnecker v. Sarver, 710 N.W.2d 726 (Wis. Ct. App. 2006) (noting that a second order was in another state). Further, he may be married to or cohabiting with another woman with whom he shares children not subject to a child support order, but whom he is legally obligated to support. A recent analysis found family complexity to exist in about three quarters of TANF families. Daniel R. Meyer et al., Multiple Partner Fertility: Incidence and Implications for Child Support Policy (Inst. For Research on Poverty, Discussion Paper no. 1300-05, May 2005), available at www.irp.wisc.edu/ publications/dps/pdfs/dp130005.pdf.

172 See Bowen v. Bowen, 47t So. 2d 1274, 1276 (Fla. 1985) (finding voluntariness where obligor was laid off, remained unemployed for seven months, and during that time conducted diligent search according to uncontroverted evidence); Dorner v. McCarroll, 271 A.D.2d 530 (N.Y. App. Div. Apr. 10, 2000) (stating that failure to seek employment constitutes willful violation of support order); see also Rodriguez, 102 P.3d at 45 (holding underemployment negates "indigency" for purposes of appointment of counsel); $c f$. Russell v. Armitage, 697 A.2d 630 (Vt. 1997) (finding failure to vigorously pursue workers' compensation claim ast willful violation).t

Similar issues may exist in regard to periods of imprisonment for criminal offenses. Somet courts treat these as periods when the obligor was unable to comply for purposes of the contempt determination, State ex rel. Burkhart v. Nold, No. C2-02-1983, 2003 WL 21524991, att *4 (Minn. Ct. App. July 8, 2003), or even suspend payments during the period of incarceration. Long v. State, 807 A.2d 1, 4 (Md. 2002). Others require evidence of the obligor's actualt income during the period of incarceration. In re A.P., 46 S.W.3d 347, 349-50 (Tex. 2001).t Still others treat imprisonment the same as voluntary unemployment, on the theory that obligor by his own wrongful conduct has placed himself in a position that precludes gainfult employment. Rhodes v. Rhodes, No. 00 BA 34, 2001 WL 1199877, at *1-3 (Ohio Ct. App.t Sept. 25, 2001).t

173 In some jurisdictions the obligor's ability to borrow funds is considered relevant in determining ability to pay, e.g., Tex. FAM. CODE ANN. \$ 157.008 (Vernon 2002), creating factual questions concerning identification of potential lenders and their willingness to lend. A Texas statute, for instance, makes the "inability to pay" defense available only if the obligor has attempted unsuccessfully to borrow, but the statute does not specify the required breadth or diligence of those attempts. Id. In other jurisdictions, the courts have rejected attempts to 
owned by others ${ }^{174}$ to satisfy the obligor's debt. There may be legal as well as factual components to these issues. ${ }^{175}$ The complexity of these issues puts them beyond the understanding of most indigents, who will rarely be able to effectively respond to the petitioner's case in these areas, much less present a case in chief of their own. Even the simplest "inability to pay" argument requires articulating the defense, gathering and presenting documentary and other evidence, and responding to legally significant questions from the bench-tasks which are "probably awesome and perhaps insuperable undertakings to the uninitiated layperson." 176 This is particularly true where the layperson is indigent and poorly educated.

Adding to the obligor's burden is the potential that the court will hold his or her testimony concerning inability to pay to be insufficient evidence or lacking in credibility in the absence of documentary corroboration. ${ }^{177}$ Retention of the necessary records among indigents is rare, particularly given the widespread instability in their employment, housing, and other aspects of their lives. Even in the many states in which the civil contemnor has a right to appointed counsel, the lack of documentary evidence makes it difficult for the attorney to prove to the satisfaction of the court his client's inability to pay. The indigent contemnor without counsel will rarely if ever be able to do so.

\section{Ce The Role of Judicial Perceptions and Attitudese}

The most disturbing aspect of the case law, and a significant contributor to inappropriate coercive incarcerations, is the frequency with which indigent child support obligors are imprisoned as a result of trial courts' abuse of their civil contempt authority. Repeatedly, the reported

include ability to borrow in the "ability to pay" determination. See Phillips v. Knox, No. E2000-02988-COA-R3-JV, 2001 WL 1523347, at *9 (Tenn. Ct. App. Nov. 29, 200t) (citing and following Netherton v. Netherton, No. 01-A-01-9208-PB00323, 1993 WL 49556, at *3 (Tenn. Ct. App. Feb. 26, 1993)).

174 See Gawerc, 165 S.W.3d at 315 (Tex. 2005).

175 A case may also implicate state and federal statutory limits on the proportion of an obligor's disposable earnings that can be subjected to child support obligations. See Consumer Credit Protection Act, 15 U.S.C. § 1673(b) (2007); Ohio Rev. Cone AnN. § 3121.03 (LexisNexis 2003); Patterson v. Patterson, No. 86282, 2005 WL 247t 0t 2 (Ohio Ct. App. Oct. 6, 2005).

176 Pasqua v. Council, 892 A.2d 663, 673 (N.J. 2006).

177 See, e.g., Falkner v. Falkner, 769 So. 2d 933, 934-35 (Ala. Civ. App. 2000); Larsen v. Larsen, 949 So. 2d 278, 279 (Fla. Dist. Ct. App. 2007); Davison v. Miss. Dep't Human Servs., 938 So. 2d 912 (Miss. Ct. App. 2006) (discussing documentation of disability); Stuber v. Stuber, No. 1-02-65, 2003 WL 1826294, at *4 (Ohio Ct. App. Apr. 9, 2003); DHS v. Rhea, No. E2005-00330-COA-R3-JV, 2006 WL 770518 (Tenn. Ct. App. March 27, 2006) (discussing documentation of job search); Phillips, 2001 WL 1523347 at *8; Ex parte Garrison, 853 S.W.2d 784, 787-88 (Tex. App. 1993). 
cases show deviations from fundamental procedural requirements and establishment of purge amounts known to exceed obligors' ability to pay.

Reports of these cases demonstrate the actualization of concerns long expressed about the potential for abuse that is inherent in unfettered judicial discretion to impose contempt sanctions. The Supreme Court has described the civil contempt authority as uniquely susceptible to abuse, the untrammeled power which it places in the individual judge creating the "prospect of "the most tyrannical licentiousness." 178 The Court identified cases involving difficult fact-finding as particularly susceptible to the arbitrary exercise of judicial power in the absence of procedural constraints. ${ }^{179}$ These concerns were elaborated on in a leading article by Earl Dudley:

The concern for judicial bias in contempt proceedings comprehends not merely the formulation of powerful sanctions but the fact-finding process as well. Findings of fact in contempt proceedings are insulated from meaningful appellate review by the "clearly erroneous" standard. Thus, a judge sitting without a jury in a civil contempt proceeding . . . has enormous power to give rein to his biases under the guise of resolving disputed issues of fact. ${ }^{180 t}$

Dudley cautioned against the "grave potential for biased adjudication" in any contempt case involving a factual dispute. ${ }^{181 t}$

In almost every case the judge will already have ruled once on the merits against the party accused of violating an outstanding order. He may perceive the party's subsequent conduct as evasive of his commands and be unwilling to listen to proffered explanations, or may bring to the contempt proceeding adverse judgments about motivation or credibility formed earlier. ${ }^{182 t}$

Appellate courts in several states have expressed concern with the repeated abuses of judicial authority in contempt adjudications, often citing the specific problem areas identified by Dudley. Faced with a case containing serious procedural irregularities, the Florida Court of Appeals observed,

178 See Int'l Union, United Mine Workers v. Bagwell, 512 U.S. 821,t831 (1994).

179 See id. at 833-34.

180 Dudley, supra note 34, at 1078 (citing the "inability to pay" issue in child support contempt proceedings as one potentially subject to judicial bias (citation omitted)).

181 Id. at 1079.

182 Id.; accord Bagwell, 512 U.S. at 83t ("Contumacy 'often strikes at the most vulnerable and human qualities of a judge's temperament.'”) (quoting Bloom v. Illinois, 391 U.S. 194 (1968)). 
We are deeply troubled that circuit courts continue to illegally incarcerate people for civil contempt in the face not only of ample case law, but also a rule which clearly delineates the procedures that should be followed in order to ensure that the due process rights of alleged contemnors are protected. ${ }^{183 t}$

Similarly strongly worded denunciations have been directed at the pervasive practice of knowingly imposing excessive purge amounts on indigent contemnors. This practice has been repeatedly denounced by the Maryland appellate courts, commencing in a 2000 case in which the Court of Appeals reviewed three joined cases:

These cases, hopefully, represent the worst in disregard for proper, mandated procedure. . . . [T]he purge amounts recommended by the master, and approved by the court, were conjured up out of nothing. There was not a scintilla of evidence to support a conclusion that Thrower, Mason, or Miles then had or could possibly obtain the ability to pay the purge amounts within the time set, in order to avoid incarceration. It defies any semblance of logic or human experience to suppose that, on $\$ 69 /$ week unemployment benefits and with no other significant assets, Thrower would be able to pay $\$ 840$ within a month or that on $\$ 75 /$ week, Mason would be able to pay $\$ 900$ in three weeks. And for the master to take judicial notice that jewelry worn by Miles, who had no other assets and no employment, and who was being supported entirely by his mother, was worth $\$ 4,190.76$ [the exact amount of the arrearage], is so far removed from reality as to suggest an actual disdain for proper judicial procedure and temperament. ${ }^{184}$

183 Bresch v. Henderson, 761 So.2d 449,t451 (Fla. Dist. Ct. App. 2000). In this case thet obligor had appeared in court for a hearing in a modification proceeding. Apparently on its own initiative, without notice to the obligor, and without making specific factual findings, the trial court determined that the obligor was behind in his support payments, held him in contempt, and ordered him incarcerated indefinitely subject to a $\$ 1,000$ purge. Id. at 450 . Accord Conley v. Cannon, 708 So. 2d 306, 307 (Fla. Dist. Ct. App. 1998) (chastising trial courts for their "studied indifference to procedural due process" in contempt cases). For other examples of cases involving multiple procedural irregularities, see In re State Dep't of Soc. Servs. ex rel T.M.A. v. Pickens, 972 So. 2d 1225 (La. Ct. App. 2007); Bryant v. Howard County Dep't oft Soc. Servs., 874 A.2d 457 (Md. 2005); Thrower v. State Bureau of Support Enforcement, 747t A.2d 634, 642-43 (Md. 2000); In re McDonald, No. 01-05-00616-CV, 2005 WL 2124155t (Tex. App. 2005); see also Slagle v. Slagle, No. 2004-L-119, 2005 WL 2002272 (Ohio Ct.t App. 2005) (affirming imprisonment for contempt despite ambiguity of court order).t

184 Thrower, 747 A.2d at 642-43. 
That the three cases before the court in Thrower $v$. State Bureau of Support Enforcement were representative of a widespread problem is evidenced by the subsequent Maryland cases in which appellate courts were forced to reiterate Thrower's rebuke ${ }^{185}$ and by the number of cases from other jurisdictions in which the facts on record, statements made by the finder of fact, or both leave no doubt of the contemnor's inability to pay the purge amount. ${ }^{186 \mathrm{e}}$

The various abuses noted above may reflect trial judges' faith in the correctness of the amounts that indigent obligors have been ordered to pay and their misunderstanding of the realities of employment at the low end of the economy. Caught up in the important goal of meeting the economic needs of America's children and the norms of parental responsibility, they can become frustrated with the repeated court appearances of obligors with huge arrearages, a history of nonpayment, and an endless stream of what seem to be excuses for not providing for their children. ${ }^{187}$ They may feel the need to vindicate the authority of the court and its orders against persons who appear to be "flaunt[ing] their defiance of properly entered court orders."188

The frustration and ambivalence are apparent in statements made by judges imposing coercive imprisonment on non-paying obligors. An Ohio trial court judge stated to the obligor:

185 See Bryant, 874 A.2d at 469 n.4 (holding that the imposition of a $\$ 1,000$ purge amount for obligor who earned $\$ 8$ per hour and had two other children to support was based on "sheer speculation”); Long v. State, 807 A.2d 1, 11-13 (Md. 2002) (reversing an intermediate court's decision to impose conditions on the release of an obligor ordered incarcerated despite lack of a finding that he was able to pay purge amount); Rawlings v. Rawlings, 766 A.2d 98, 118 (Md. 2001) ("As in Thrower, '[T]here was not a scintilla of evidence to support a conclusion' that Petitioner . . . had the current ability to purge . . .." (citation omitted)).

186 See, e.g., supra note 163 and accompanying text; see also MAY \& ROULET, supra note 13, at 43-44 (reporting on an observation of purge hearings for Chicago obligors who were serving civil contempt sentences:

Each one attested to the fact that he did not have the money to pay child support, could not raise the money from family or acquaintances and stated that as long as he was held in jail, he would be unable to earn the money necessary to pay child support. In spite of this repeated scenario, each such defendant was returned to jail for two additional weeks and a hearing before another judge was set for that date.).

187 MAY \& Roulet, supra note 13, at 43 (concluding after observing child support contempt proceedings in several states thatt" $[\mathrm{w}]$ hen judges hear child support cases regularly they are more likely to become jaded to the 'excuses' of parents who have not paid their child support obligations. Such excuses must seem repetitious and insincere when heard consistently."); see Kaufman, supra note 136 (quoting service provider to homeless men:

In theory you are supposed to be able to go into court and you are supposed to be able to get modifications .... . But in reality, there are a lot of judges who are sick and tired of dads who haven't paid child support. They don't want to hear you had a drug problem or were in prison. They just want the money and they don't even care if you can't pay it.).

188 Thrower, 747 A.2d at 642.t 
You owed somewhere in the neighborhood of $\$ 75,000$ so, you know, what you've been paying is basically a drop in the bucket and I just feel like we've been going round and round on this for too long now and we're not getting anywhere, we keep going in circles. And, you know, I appreciate the fact that you can't get blood out of a turnip; if you can't get a decent job, you can't keep up with your support, but I feel that this court has been more than fair with you in the past and bent over backwards .... ${ }^{189 t}$

A Maryland trial court judge noted:

Okay, sure, he can't pay now 'cause he's in jail for failure to appear, ... but there was just a blatant disregard back in May, June, July and August. I can't hide that. ${ }^{190 t}$

A circuit court judge in Wisconsin stated:

[W] hile I sympathize with Mr. Sarver, because I don't think it's realistic that right now he's going to be able to make these payments, I can't ignore the size of the file either. This issue has been going on for a while. ${ }^{191}$

Appellate courts have acknowledged this frustration. ${ }^{192}$ However, understandable as trial courts' frustration may be, they abuse their authority when expressing their frustration or vindicating their authority by depriving persons of their liberty for the offense of being unable to pay a support award that may well have been excessive in the first place.

The above cases involved abuses in ordering incarceration and setting purge amounts. Though less often specifically identified in the appellate cases, similar abuses can occur in determining that the obligor is in contempt. In particular, abuses can take the form of inappropriate findings that an obligor's unemployment was voluntary, that he has not been sufficiently diligent in seeking work, or that the obligor was voluntarily under-employed. ${ }^{193}$ Findings of this sort negate the defense of in-

189 State v. Majoras, No. E-00-048, 2001 WL 640929, at *3 (Ohio Ct. App. June 8, 2001) (emphasis omitted) (quoting the trial court as it revoked probation following the obligor's conviction for criminal non-support).

190 Long, 807 A.2d at 5.

191 Zinnecker v. Sarver, No. 2005AP2195, 2006 WL 120066, at*1 (Wis. Ct. App. Jan. 18, 2006).

192 See Int'l Union, United Mine Workers v. Bagwell, 512 U.S. $821, t 831$ (1994); Lewis v. Lewis, 875 S.W.2d 862, 864 (Ky. 1993); Thrower, 747 A.2d at 642.

193 See In re Warner, 905 A.2d 233, 242-43 (D.C. 2006); Herrera v. Sanchez, 885 So.2d 480,t481 (Fla. Dist. Ct. App. 2004); Clark v. Gragg, 614 S.E.2d 356, 359-60 (N.C. Ct. App. 2005); State ex rel Phillips v. Knox, No. E2000-02988-COA-R3-JV, 2001 WL 1523347, at*3 (Tenn. Ct. App. Nov. 29, 2001). 
ability to pay, leading to a finding that disobedience of the child support order was willful, and hence contemptuous. ${ }^{194 t}$

\section{Implications of Improper CONFinemente}

\section{A. Social Effects}

Serious social problems result from this phenomenon of jailing indigent parents. Not the least of these is the fact that coercive imprisonment of those who are unable to pay is counterproductive to the goals of the child support enforcement program itself. ${ }^{195}$ During the term of imprisonment, the contemnor is largely disabled from generating the income necessary for payment of child support. ${ }^{196} \mathrm{He}$ also is incapable of providing any other form of support or assistance to the child or the custodial parent. Furthermore, imprisonment causes some contemnors to lose jobs from which wage withholding was providing or could have provided some level of support. ${ }^{197 t}$

The prospect of imprisonment causes a substantial number of indigent fathers to "go underground," leaving the home state and subsisting through sources of income that will not reveal the individual to the child support enforcement system. ${ }^{198}$ Not only does this cost the child whatever economic support might have been provided by the father, but it also removes any prospect of a social relationship between father and child, with the varied emotional and psychological benefits for the child that can arise from such a relationship. ${ }^{199}$ In addition, non-custodial par-

194 See, e.g., T.L.D. v. C.G., 849 So. 2d 200, 206-07 (Ala. 2002).

195 See Rodriguez v. Eighth Judicial District Court, 102 P.3d 41, 46 n.9 (Nev. 2004) (acknowledging counterproductiveness of extended jail stays for child support contemnors); Dudley, supra note 34, at 1076 (expressing view that dangers of bias associated with contempt are "greatly reduced" in proceedings to enforce child support orders because imposition of contempt sanctions is in tension with the ultimate goal of providing child support); cf. Phillips, 2001 WL 1523347 att*10 (noting the counterproductiveness of driver's license revocation as a means to coerce obligor's employment and payment of child support).

196 A number of incarcerated child support obligors participate in work release programs, which allow them to generate income during the term of imprisonment. See, e.g., Black v. Div. of Child Support Enforcement, 686 A.2d 164, 167 n.4 (Del. 1996). In a work release program, an inmate may leave actual confinement during certain hours to work or, in some cases, to seek employment. Rawlings v. Rawlings, 766 A.2d 98, 119 (Md. 2001). But see Peterson v. Roden, 949 So. 2d 948, 950 (Ala. Civ. App. 2006) (noting the termination of a contemnor from work release program for rule violations).

197 See, e.g., Sevier v. Turner, 742 F.2d 262, 265-66 (6th Cir. 1984); Wilson v. Holliday, 774 A.2d 1123, 1127 (Md. 2001).

198 Cf. Nat'l Women's Law C'tr., Dollaks and Sense, supra note 85, at 11 (proposingt that excessive awards drive obligors into underground economy).

199 See, e.g., Jerrikey Rosenberg \& W. Bradford Wilcox, U.S. Dep't of Health \& Human Servs., The Importance of Fathers in the Healthy Development of Children (2006), available at www.childwelfare.gov/pubs/usermanuals/fatherhood/fatherhood.pdf.; Linda L. Dahlberg, Youth Violence in the United States: Major Trends, Risk Factors, and Preventive Approaches, 14 AM. J. Prev. Med. 259 (1998). 
ents working in the underground economy are subject to exploitation by unscrupulous employers and may see criminal activity as their only alternative for economic survival. ${ }^{200}$

\section{Be Due Process Violationse}

From a legal perspective, the widespread civil incarceration of persons who are unable to meet the conditions of their release presents a significant due process problem. The cavalier treatment of coercive imprisonment for civil contempt has been justified by the assumption that the civil contemnor can obtain release at any time by complying with the court order, and hence "holds the keys of his prison in his own pocket."201 This is not the case with regard to indigent child support obligors. Large numbers of these persons have been jailed subject to conditions of release that they are unable to meet. "Because it is impossible to coerce that which is beyond a person's power to perform, once the confinement ceases to have any coercive impact, continued imprisonment for civil contempt constitutes a violation of due process."202 Under these circumstances, the coercive civil sanction is transformed into a criminal punishment which has been imposed in violation of the Constitution. ${ }^{203}$ The very fact of the incarceration of large numbers of civil contemnors who are unable to meet the conditions of release is thus in itself a serious due process violation. ${ }^{204}$

In addition, the processes by which these indigents came to be incarcerated are reflective of widespread deviations from fundamental fairness and demonstrate the need to re-examine the civil-criminal distinction in applying the Due Process Clause to contempt proceedings. In United Mine Workers v. Bagwell, a case involving complex labor injunctions, the Court acknowledged the possibility that some civil contempt cases may demand more than the rudimentary "notice and hearing" level of due process that has traditionally been accepted, and expressed reservations about the widely differing treatment of civil and criminal contempt. $^{205}$ The Court suggested that heightened procedural protections may sometimes be necessary in ostensible civil contempt proceedings in

200 See Ann Cammett, Expanding Collateral Sanctions: The Hidden Costs of Aggressive Child Support Enforcement Against Incarcerated Parents, 13 GEO. J. ON PoverTy L. \& POL'y. 313, 327 (2006).

201 See Ridgway v. Baker, 720 F.2d 1409, 1413 (5th Cir. 1983).

202 Taylor v. Johnson, 764 So. 2d 1281, 1282 (Ala. Civ. App. 2000).

203 See Bresch v. Henderson, 761 So. 2d 449, 450 (Fla. Dist. Ct. App. 2000).

204 The duration of a civil contempt sentence can be as brief as a few days, or it can be a year or more, or even unlimited. E.g., Clark v. Gragg, 614 S.E.2d 356 (N.C. Ct. App. 2005); In re Brownhill, No. 14-07-00346-CV, 2007 WL 1624776 (Tex. App. June 7, 2007).

205 Int'l Union, United Mine Workers v. Bagwell, 512 U.S. 821, 832-33 (1994). 
order to protect parties from erroneous deprivations and to prevent the arbitrary exercise of judicial power. ${ }^{206 t}$

The Court based its categorization of the proceedings as criminal on three primary factors: ${ }^{207 t}$

(1)e Factual Complexity: The complexity of the fact questions involved in a case increases the need for more extensive ande even-handed fact-finding processes in order to promote accuracy. The Court stated in Bagwell that the "need for extensive,e impartial fact-finding is less pressing" when the alleged disobedience involves "discrete, readily ascertainable acts, such ase turning over a key."208t

(2)e Seriousness of the Potential Penalty:eln Bagwell, the Court felte that the magnitude of the potential penalty-more than $\$ 32$ million in fines - demanded a high degree of procedural regularitye in order to protect against error. ${ }^{209 t}$

(3)e Potential for Abuse: Overlying all contempt proceedings is thee compromised neutrality of the judge, which can lead to arbitrarye decision-making and other abuses of discretion. ${ }^{210 t}$

These three factors also support greater procedural regularity in child support contempt cases where an obligor who arguably lacks the ability to pay the ordered support is threatened with coercive imprisonment. Although the finding in Bagwell was limited to the situation before the Court, the holding demonstrates the Court's concern with the skeletal fact-finding procedures that have been accepted in civil contempt proceedings, and signals a potential for heightened due process scrutiny of such proceedings in the future.

206 See id.

207 See id. at 833-34 (citing two additional factors to justify the use of summary procedures to adjudicate "direct contempt," that is, contempt occurring in the courtroom during court proceedings: (1) the need for procedural minimalism in order for the court to maintain order and conduct its proceedings and (2) the reduced danger of erroneous fact-finding when the judge has first-hand knowledge of the facts).

208 Id. at 833. The Court used "payment of a judgment" as another example of a violation involving a simple, affirmative act where assurance of disinterested fact-finding and evenhanded adjudication was less pressing. In child support contempt cases where ability to pay is an issue, the assumption does not hold. Dudley, supra note 34, at 1078-79. The potential complexity of the factual issues, together with the history of judicial abuse in this area and the seriousness of the incarceration penalty that is so of ten used in these cases easily warrants an expansion of protective procedures beyond those currently available.

209 Bagwell, 512 U.S. at 831 ("To the extent that such contempts take on a punitive character, however, and are not justified by other considerations central to the contempt power, criminal procedural protections may be in order.”)

210 Id. at 834 ("The risk of erroneous deprivation from the lack of a neutral factfinder may be substantial."). 
An alternative method for analyzing the appropriateness of heightened procedural protections in civil contempt cases is to apply due process standards to particular rights and procedures using the Mathews $v$. Eldridge standard. ${ }^{211}$ This test determines what process is due in a given proceeding based on analysis of the private interests at stake, the government's interest, and the risk that the procedures used will lead to erroneous decisions. ${ }^{212}$ The numerous state and federal holdings that have recognized a right to counsel for contemnors facing possible imprisonment have been based on this analysis. ${ }^{213}$ These rulings emphasize the weight of the individual's interest in avoiding incarceration and the high risk of error if counsel is not provided, and find that these concerns easily outweigh the state's interest in administrative convenience.

Indeed, the private interest at stake in civil contempt proceedings enforceable by coercive imprisonment is of the highest order: the potential loss of liberty through incarceration by the state. In fact, the loss of liberty through civil contempt can be greater than for criminal contempt, due to the potentially greater duration of the confinement. ${ }^{214}$ And, as one court noted, "from the perspective of the person incarcerated, the jail is just as bleak no matter [whether the incarceration is labeled civil or criminal]." 215

The state's interest in providing financial support for children (or repaying the state for welfare benefits provided to a child) cannot justify procedural laxness that results in imprisonment of those unable to pay the purge amount. Not only is the coercive effect absent, but imprisonment has the counterproductive effect of reducing the obligor's ability to generate the resources necessary for future payment. The government's interest in administrative convenience and cost reduction has repeatedly

211 See, e.g., Smoot v. Dingess, 160 W. Va. 558, 561 (W. Va. 1977) (declaring that due process requires sworn testimony and preparation of a transcript in civil contempt proceedings leading to incarceration).

212 Mathews v. Eldridge, 424 U.S. 319, 335 (1976).

213 E.g., Henkel v. Bradshaw, 483 F.2d 1386 (9th Cir. 1985); Walker v. McLain, 768 F.2d 1181 (10th Cir. 1985); Sevier v. Turner, 742 F.2d 262 (6th Cir. 1984); Ridgway v. Baker, 720 F.2d 1409 (5th Cir. 1983); Lake v. Speziale, 580 F. Supp. 1318 (D. Conn. 1984); Dube v. Lopes, 481 A.2d 1293 (Conn. Super. Ct. 1984); Black v. Div. of Child Support Enforcement,t 686 A.2d 164 (Del. 1996); Campbell v. Manning, 697 So. 2d 1020 (Fla. App. 1997); Marks v.t Tolliver, 839 N.E.2d 703 (Ind. App. 2005); McNabb v. Osmundson, 315 N.W.2d 9 (Iowat 1982); Rutherford v. Rutherford, 464 A.2d 228 (Md. 1983); Mead v. Batchlor, 460 N.W.2dt 493 (Mich. 1990); Cox v. Slama, 355 N.W.2d 40tl (Minn. 1984); Allen v. Sheriff, 511 N.W.2dt 125 (Neb. 1994); Pasqua v. Council, 892 A.2d 663 (N.J. 2006); McBride v. McBride, 431t S.E.2d 14 (N.C.1993); State v. Gruchalla, 467 N.W.2d 451 (N.D. 1991); Ex Parte Gonzales,t 945 S.W.2d 830 (Tex. Crim. App. 1997); Russell v. Armitage, 697 A.2d 630 (Vt. 1997); Tetrot v.tTetro, 544 P.2d 17 (Wash. 1975); Smoot v. Dingess, 236 S.E.2d 468 (W. Va. 1977); State v. Pultz, 556 N.W.2d 708 (Wisc. 1996); see also Parcus v. Parcus, 615 So. 2d 78 (Ala. 1993)t (applying state rule requiring counsel).t

214 McBride, 431 S.E.2d at 19 n.3.

215 Walker, 768 F.2d at 1183. 
been held insufficient to justify denial of procedural safeguards to contemnors facing civil incarceration. ${ }^{216}$

Without examining in detail the risk of error associated with specific procedures, it can be readily concluded that the procedures now in place leave a wide margin for error in regard to the critical fact of the low-income obligor's ability to pay either the ordered child support or the purge amount. Indigent obligors bear the burden of pleading and proving their inability to pay, a burden made heavier by trial courts' frequent skepticism concerning their credibility. The issues as to which these obligors bear the burden can be complex, and subject to presumptions, pleading technicalities, and other obstacles for these uninitiated laymen. In many states they have no right to appointed counsel, and in states that provide counsel, the trial courts appear willing to find waiver of that right in highly questionable circumstances. ${ }^{217}$ The risk that this procedural milieu will result in an erroneous finding of ability to pay is immense.

Application of the Mathews v. Eldridge analysis thus leads to the conclusion that current civil contempt procedures do not provide obligors with a fundamentally fair hearing on the issue of ability to pay, and hence violate the Due Process Clause. Correction demands thorough reexamination of the policies and procedures by which coercive imprisonment is imposed on child support contemnors.

\section{VI.e Supporting Children vs. Punishing Poverty:e Re-Calibrating the System}

Enforcement of the child support obligations of non-custodial parents is an important and difficult task. The present federal/state child support enforcement system developed over a number of years, with adjustments being made and new tools added as experience demonstrated a need. Adjustments that focused on enhancing the states' ability to locate recalcitrant obligors and their assets and extract payment have produced the effective machine for supporting America's children that policy makers and child advocates envisioned.

216 See, e.g., Walker, 768 F.2d at 1184 ("While the state does have an interest in minimizing the cost of such proceedings, this interest in monetary savings cannot outweigh the strong private interest of the petitioner and the substantial procedural fairness achieved by providing a lawyer for the indigent defendant in a civil contempt proceeding.").

217 E.g., Arrington v. Dep't of Human Res., 935 A.2d 432, 438 \& n.6 (Md. 2007); Thrower v. State Bureau of Support Enforcement, 747 A.2d 634, 642-43 (Md. 2000) (criticizing "the farce that passed for a waiver inquiry" by the trial judge); Blackston v. Blackston, 802 A.2d 1124 (Md. Ct. Spec. App. 2002); N. v. A.R., Nos. E-00-036, E-00-037, 2001 WL 127343t (Ohio Ct. App. Feb. 16, 2001); Cottingham v. Cottingham, 193 S.W.3d 531, 536-37 (Tenn.t 2006); In re Cohen, No. 2-06-334-CV, 2006 WL 3438060 (Tex. Ct. App. Nov. 30, 2006).t 
Experience also has demonstrated, however, that for many noncustodial parents the problem is deeper and more complex than recalcitrance. Although recalcitrance may be part of the picture, it is subsumed in the larger problems of poverty. ${ }^{218}$ The challenges for programs seeking child support from these parents lie in accurately assessing a reasonable child support award, retaining sufficient enforcement flexibility to accommodate frequent changes in ability to pay, and using enforcement tools in a way that comports both with due process and achievement of the goals of the program. Failures of the child support enforcement system in these areas have been compounded by the failures of the legal system in administering its awesome contempt power, to the end that indigent parents are deprived not only of their assets, but their physical liberty as well.

\section{Avoiding Arrearages: Systemic Corrections}

Recently, some attention has turned to avoiding the accrual of unwarranted and uncollectable arrearages. In particular, the agencies that administer the child support enforcement system have begun to experiment with adjustments to better accommodate the situations of indigent obligors. The federal Department of Health and Human Services is itself encouraging states to modify systemic mechanisms that lead to non-willful accrual of arrearages, to develop expedited procedures for modifying support awards when circumstances change, and to forgive the state share of accrued arrearages in certain circumstances. ${ }^{219}$

Reforms in these areas are badly needed and will go far toward reducing the incidence of improper incarceration, particularly in relation to future child support orders. However, reforms in this area are in their infancy, and few states have made the significant adjustments in their

218 Policy makers working with the reformed welfare program (Temporary Assistance for Needy Families, or TANF) have come to realize that there are numerous barriers that impede successful job placements for indigent persons. These barriers include physical and mental health problems, lack of transportation, substance abuse, and lack of education or job skills. See supra notes 66-72 and accompanying text.

219 See, e.g., Office of Child Support Enforcement, Managing Child Support Arrears, A Discussion Framework: Summary of the Administration for Children and Families RO I, II \& III Third Meeting on Managing Arrears (2003), available at http:// www.acf.hhs.gov/programs/cse/pubs/2003/reports/arrears (last visited Mar. 12, 2009); OFFICE of Child Support Enforcement, Policy Interpretation Questions for 1999 (1999), available at http://www.acf.hhs.gov/programs/cse/pol/PIQ/1999/piq-9903.htm (last visited Mar. 12, 2009); Office of Child Support Enforcement, Policy Interpretation QuesTIONS FOR 2000 (2000), available at http://www.acf.hhs.gov/programs/cse/pol/PIQ/2000/piq00-03.htm (last visited Mar. 12, 2009). The success of forgiveness programs is limited by thet fact that although states and custodial parents may accept less than full payment of childt support arrearages owed them, the same is not true of any portion of the arrearages owed to thet federal government. Office of Child Support Enforcement, Policy Interpretaiton QuesTIONS FOR 2000, supra. 
child support guidelines and related laws and practices that are necessary to correct the problems identified by this paper. Even if such reforms were widespread, additional measures would be necessary to reduce or eliminate improper use of coercive incarceration in regard to existing orders and already-accrued arrearages. Any of the following would be steps toward a more just and productive system.

\section{VIII.e Avoiding Contempt Charges: INTERVENTION AND COMPROMISE}

\section{A. Diversion of Contempt Cases}

Laws or rules in some states provide for automatic initiation of contempt proceedings when a certain number of payments have been missed or when arrearages reach a certain level. ${ }^{220}$ Mandatory contempt laws such as these should be modified to allow an assessment of the defendant's means for reaching program goals prior to the filing of a contempt action. In many cases, modification of the support amount, forgiveness of arrearages, or enrollment in a fatherhood program may be more appropriate. Contempt charges should generally be foregone or dismissed if the obligor is working, wages are being withheld at an appropriate level, and the obligor has no other source of revenue. If an indigent obligor is employed, and his wages are subject to withholding to meet the child support obligation, a coercive contempt proceeding adds little or nothing toward the achievement of program objectives. It is in these cases that incarceration is most counterproductive. Similarly, contempt charges should not be pursued against an obligor who is participating in a program that provides assistance with employability skills, job placement, and responsible fathering. The desirability of more individualized approaches to enforcement was recognized by the federal Department of Health and Human Services, which recommended in its Strategic Plan for 2005-2009 that enforcement approaches be customized to distinguish between those who refuse to pay and those who cannot pay. ${ }^{221}$

\section{B.e Bradley Amendment/Forgiveness of Federal Sharee}

The individuals currently being imprisoned on account of their failure to pay unwarranted arrearages can be truly helped only if a mechanism exists to forgive or adjest the amount of the accrued debt. Otherwise, they will continue to live under threat of arrest and incarceration, which will affect their choices concerning residence, relationships,

220 E.g., S.C. R. FAM. Cт. 24; 9тh Jud. Dist., N.M. R. C'т. Form 9-608.

221 U.S. Dep't of Health \& Human Servs., National Child Support Enforcement: Strategic Plan FY 2005-2009, at 12 (2004), available at http://www.acf.hhs.gov/programs/ cse/pubs/2004/Strategic_Plan_FY2005-2009.pdf. 
and sources of income. Problems relating to arrearages that have already accrued can be fully addressed only by modifying the Bradley Amendment's prohibition on retroactive modification of child support awards.

A prohibition on reduction of accrued child support debt serves an important purpose when the system has functioned properly, producing a reasonable child support award that is within the means of the obligor. The problem with the prohibition is that it leaves no room for correction of error. Nor does it allow for forgiveness of child support debt in the context of programs aimed at promoting the individual's long-term economic and social contribution to the child. An appropriately worded amendment to the law could create exceptions that would enable courts and child support agencies both to relieve individuals from unconscionable, if not unconstitutional, debts and to fully re-engage absent parents in the lives of their children.

\section{Avoiding Imprisonment: Justice in Contempt Proceedings}

The above measures are aimed at reducing inappropriate contempt incarcerations by enhancing low-income obligors' ability to remain in compliance with the court order. Without noncompliance, there is no contempt, and hence there should be no incarceration for contempt. Even universal implementation of such measures, however, would not eliminate either willful or non-willful non-compliance with child support orders by low-income obligors. Consequently, measures to assure due process for low-income persons threatened with civil incarceration are vital whether or not reforms in the mechanisms for setting and modifying support awards are undertaken. Without such reforms, civil contempt process will remain the highly discretionary judicial preserve that it was in common law England, with none of the procedural niceties that limit courts' ability to deprive persons of physical liberty in the criminal realm. ${ }^{222 t}$

\section{A. Judicial Education}

It has been argued that avoidance of error in contempt proceedings can be adequately accomplished through education and training of judges, and this view was recently accepted by the New Jersey Court of Appeals. ${ }^{223}$ Training and education of judges on matters relevant to correct decision-making in civil contempt cases involving low-income child support obligors would indeed be helpful. Trial courts have little experience with adjudicating child support issues in this population, as child support litigation between indigent parents was infrequent prior to the

222 See, e.g., S.C. R. FAм. Cт. 24; 9тн Jud. Dist., N.M. R. Cт. Form 9-608.

223 Pasqua v. Council, 892 A.2d 663, 669 (N.J. 2006). 
federal legislation. Moreover, by replacing judicial with administrative authority in the earlier stages of most child support proceedings involving indigents, the system limits the opportunities for judges to become familiar with the circumstances of these parties. Thus, real reform does demand improvement in judicial understanding of the jobs and job-seekers in the low end of the economy so that judges have a better factual basis on which to decide issues such as underemployment and imputed income.

However, the magnitude of the coercive incarceration penalty, the frequency with which it appears to be imposed, and the number of cases evidencing abuse of judicial authority in this area demand more concrete protections against abuse of discretion and other sources of error. Indeed, the New Jersey Court of Appeals was reversed by the New Jersey Supreme Court, denying that the "good intentions and fair-mindedness of a Superior Court judge are . . . an adequate constitutional substitutee [the Constitution's procedural protections] when a jail term is stake."224 The court continued, "However well intentioned and scrupulously fair a judge may be, when a litigant is threatened with the loss of his liberty, process is what counts." $225 t$

\section{Be Burden of Proofe}

Of particular importance in creating an environment conducive toe abuse of judicial discretion in child support contempt cases are the rules and practices related to proving the critical element of "ability to comply." In criminal contempt proceedings, the prosecution has the burden of not only proving, but proving beyond a reasonable doubt, that the obligor had the ability to comply with the child support order. In a civil contempt proceeding, however, "inability to comply" is treated as a defense to the charge of contempt. ${ }^{226}$ The issue, though central to the element of willfulness, will not be considered unless the obligor raises the issue and presents a prima facie case. In many jurisdictions the obligor carries not only the burden of production, but also the burden of proof on the issue of inability to pay. The indigent obligor's inherent difficulties in meeting this burden are compounded by the virtually unlimited discretion of the court to disregard testimony or other evidence presented by the obligor as lacking in credibility.

The comparative potential for an erroneous finding of contempt between civil and criminal contempt proceedings is thus dramatic. In the criminal context, proof of willfulness beyond a reasonable doubt must

$224 I d$. at 670.

225 Id. at 673 .

226 Paul M. D. Harrison, Equity: Financial Inability to Comply with a Decree: Imprisonment for Debt, 48 Мich. L. REv. 877, 877-79 (1950). 
precede incarceration. In the context of civil contempt, there is a presumption of willfulness which must be rebutted by an indigent and unsophisticated obligor in order to avoid incarceration, and any attempt to do so can be and often is disregarded by the court as non-credible.

The potential for erroneous incarceration in civil contempt cases could be substantially reduced by allocating to the petitioner the burden of proof concerning ability to pay, even if the standard of proof were less demanding than the reasonable doubt standard that applies in criminal contempt cases. If the burden of going forward is to remain on the obligor, only a minimal showing should be required to make a prima facie case, and prompts by the court to elicit this evidentiary showing by the obligor should be required.

Allocation to the obligor of the burden of proof is particularly troubling when the issue is ability to pay a purge amount necessary to avoid or end imprisonment. Without the ability to purge, imprisonment must be considered criminal rather than civil, ${ }^{227}$ and cannot be imposed without a full criminal trial.228 Thus, the only thing that stands between the contemnor and his right to a jury trial with all the constitutionally required trappings is the finding of ability to pay the purge amount. The state should bear the burden of proving the facts necessary to justify the extraordinary action of imprisoning a person without these procedural protections.

\section{C.e Standard of Appellate Reviewe}

Re-allocation of the burden of proof, while important, is not sufficient to protect against abuses that lead to erroneous incarceration in child support cases. Without meaningful appellate review, a court can continue to engage in slanted or sloppy fact-finding or indulge its assumptions about the ease of finding jobs, the amount that can be earned, or the general unscrupulousness of nonpaying obligors, regardless of the burden of proof.229 A deferential "abuse of discretion" standard is normally used in appellate review of civil contempt cases. Under this standard the trial court's finding of contempt will not be reversed unless (1) the trial court's decision was unreasonable, arbitrary or unconscionable and not merely an error of law or judgment, ${ }^{230}$ or (2) there is no evidence

227 See, e.g., Walker v. McLain, 768 F.2d 1181, 1183 (10th Cir. 1985) (noting that the line between civil and criminal contempt is a fine one).

228 Mead v. Batchlor, 460 N.W.2d 493, 499-500 (Mich. 1990) (quoting Sword v. Sword, 249 N.W.2d 88, 98 (Mich. 1976) (Levin, J., concurring)).

229 See, e.g., In re Warner, 905 A.2d 233, 234 (D.C. Ct. App. 2006) (presenting a criminal contempt case tried under reasonable doubt standard).

230 Walters v. Murphy, No. 04-COA-044, 2004 WL 2757598, at*1 (Ohio Ct. App. Dec. 2, 2004). 
to support the trial court's finding. ${ }^{231}$ This highly deferential approach to review of contempt orders has its roots in the historically exclusive dominion of the trial judge in imposing contempt sanctions. As with other aspects of contempt procedure, the standard of review and the degree of discretion to be left to the trial courts in making contempt determinations should be re-examined in light of current legal norms.

Limitations on judicial review in particular areas are justified by the value of the trial judge's personal observation of persons and events during the trial, or by the absence of legal standards against which the trial court's decision can be measured.232 The substantiality of the effects of an erroneous decision is also a factor. ${ }^{233}$ The extent of judicial review in a particular area may evolve over time as experience with trial court decision making on the relevant issues provides a basis for creation by the appellate courts or the legislature of parameters to limit or guide the exercise of trial courts' discretion. ${ }^{234}$ Enactment of the federal sentencing guidelines is an example of this evolution from highly discretionary decision-making to placement of substantial limits on discretion. ${ }^{235}$

With regard to determining whether a child support obligor had sufficient means to make the required payment, it might be argued that the large number of such cases heard by the trial court gives it particular insight warranting appellate deference. However, the evidence that such expected insights either are not possessed or are ignored by many trial courts militates against reliance on this factor. Further, the severity of the consequences of error and the potential for extracting standards for decision-making from the large number of decided cases suggest that a less deferential review of trial courts' "ability to pay" determinations is now appropriate.

\section{De Assessing Obligor's Credibilitye}

Meaningful adjustment of the standard of review must take into consideration the importance of credibility determinations in trial court decision-making concerning ability to pay. Credibility determinations are normally given extreme deference by reviewing courts because of the trial judge's ability to observe visual and auditory signals of the witness'

231 Gallaher v. Breaux, 650 S.E.2d 313, 315 (Ga. Ct. App. 2007).

232 Pierce v. Underwood, 487 U.S. 552, 558-59 (1988); Martha S. Davis, Standards of Review: Judicial Review of Discretionary Decisionmaking, 2 J. App. Prac. \& Process 47, 49 (2000).

233 Pierce, 478 U.S. at 563.

234 Davis, supra note 232, at 49.

235 See Koon v. United States, 518 U.S. 81 (1995); Davis, supra note 232, at 73-74 (discussing Koon, 518 U.S. 81). 
truthfulness. ${ }^{236}$ This is a powerful argument. ${ }^{237}$ However, the importance of such observations is diminished when economic and cultural differences between judge and witness impair the judge's ability to discern whether particular statements or behaviors indicate deception or dishonesty. ${ }^{238}$ Inappropriate credibility determinations resulting from these phenomena are readily observable in child support contempt cases. However, the rule of deference to credibility determinations by the finder of fact is so firmly embedded in our legal culture that even a reviewing court that is highly skeptical of a trial court's finding on credibility will generally defer to it nonetheless. ${ }^{239}$

There is, however, some precedent for limiting fact-finders' discretion with regard to credibility. Administrative Procedure Acts at both the state and federal levels give agency decision-makers de novo fact-finding authority following a hearing before an Administrative Law Judge (ALJ), thus allowing abandonment of credibility determinations by the ALJ, despite the latter's opportunity to observe the witnesses. ${ }^{240}$

Amelioration of the problems related to credibility determination in child support contempt proceedings may not require abrogation of the trial court's discretion in this area, but it does necessitate the creation of guidelines and controls. Concerns about credibility determination focus on the credibility of low-income obligors' testimony and other evidence in regard to ability to pay. There are a variety of corrective mechanisms

236 Comment, Advantage Which the Original Trier of Facts Enjoyed over Reviewing Court from Opportunity of Seeing and Hearing Witnesses, 111 A.L.R. 741 (1937).

237 The argument may be overstated, however, as studies have indicated that people are rarely adept at interpreting such signals. See Gerald R. Miller \& Judee K. Burgoon, Factors Affecting Assessments of Witness Credibility, in The Psychology of the Courtroom 169, 191 (Norbert L. Kerr \& Robert M. Bray eds., 1982) (concluding, based on review of research concerning detection of deception, that "[i]n attempting to determine whether a communicator was lying or telling the truth, observers in most studies were right about half the time"). See generally Louis L. JafFe, Judicial Control of Administrative Action 588 (1965) ("Discretion, however valuable, can be a facade for inadequate thinking, failure to face issues, hidden experiences, or downright dishonesty.”).

238 See, e.g., Robert E. Kraut \& Donald B. Poe, Behavioral Roots of Person Perception: The Deception Judgments of Customs Inspectors and Laymen, 39 J. Personality \& Soc. Psychol. 784 (1980); Miller \& Burgoon, supra note 237.

239 See, e.g., In re Warner, 905 A.2d 233, $243-45$ (D.C. Ct. App. 2006) (Schwelb, S.J., concurring). Having noted that "in light of the trial judge's credibility findings, I cannot fault the court's affirmance of Warner's conviction," id. at 243, Judge Schwelb stated, "In the present case the trial judge apparently found that Warner refused to work when he could have worked. Although the proof that this failure was intentional was perhaps less than overwhelming, I cannot say that there was no evidence to support the finding. Thus, although the record does not reflect that the judge or the District focused on the difference between a culpable refusal to pay and genuine inability to do so as carefully as they might have done, I discern no basis for a reversal." Id. at 245 .

240 See 5 U.S.C. $\$ 557$ (2007) (“On appeal from a review of the initial decision, the agency has all the powers which it would have in making the initial decision except as it may limit the issues on notice or by rule."). 
that could ameliorate these concerns. Establishment in each state of a uniform standard for determining credibility would promote consistency and fairness in judicial decision-making. The standard should be one that gives the benefit of the doubt to indigent obligors who are burdened with child support obligations inflated by the systemic flaws discussed in this Article. ${ }^{241}$ Only in the clearest cases should voluntary underemployment be used as the basis for a contempt finding.

Another approach, which can be combined with the preceding one, would require trial courts to explain, in writing, the basis for a finding that the obligor's evidence of inability to pay is not credible, with appellate courts having authority to measure these findings against a standard of proof. With regard to the obligor's ability to pay a purge amount, a rebuttable presumption that low-income obligors lack the ability to pay would be appropriate. Obligors benefited by the presumption could be identified by characteristics such as illiteracy, poverty, intermittent employment, or disabilities.

\section{E. Representation by Counsel}

The efficacy of the above adjustments in reducing the risk of error in "ability to pay" determinations requires that indigent obligors have access to legal assistance. The Supreme Court has long recognized the importance of counsel to assuring fact-finding accuracy, stating in a 1932 case:

Even the intelligent and educated layman has small and sometimes no skill in the science of law. . . . He lacks both the skill and knowledge adequately to prepare his defense, even though he has a perfect one. He requires the guiding hand of counsel at every step in the proceedings against him. Without it, though he be not guilty, he faces the danger of conviction because he does not know how to establish his innocence." $242 t$

The Supreme Court has not ruled directly on whether counsel is required in civil contempt proceedings. ${ }^{243}$ However, at least seven federal circuit courts and the courts of approximately half the states have held that appointed counsel is constitutionally required for indigent con-

241 See Joanna Ruppel, The Need for a Benefit of the Doubt Standard in Credibility Evaluation of Asylum Applicants, 23 Colum. Hum. Rrs. L. Rev. 1 (1992).

242 Walker v. McLain, 768 F.2d 1181, 1184 (10th Cir. 1985) (quoting Powell v. Alabama, 287 U.S. 45, 69 (1932)).

243 Int'l Union, United Mine Workers v. Bagwell, 512 U.S. 821 (1994) (requiring a full criminal trial for certain alleged civil contemnors, and deciding the case by characterizing the proceedings as quasi-criminal). 
temnors threatened with coercive imprisonment. ${ }^{244}$ Most of these cases have involved indigent child support contemnors, and have focused on the importance of counsel to reduce the risk of error in determinations of ability to comply. ${ }^{245}$ They have rejected the notion that the issues involved in a civil contempt proceeding are simple and do not require the assistance of a lawyer, pointing out that even in those cases where the factual issues would be considered simple by a lawyer or judge, they are far beyond the abilities of the indigent layperson to effectively present. ${ }^{246 t}$ The many cases in which indigent contemnors have been jailed despite their inability to pay the required support ${ }^{247}$ evidence the inability of these parties to effectively articulate a defense and present credible, relevant, and persuasive testimony. Their inability to speak the language of the court is a large part of the reason that judges view their efforts to defend themselves as "excuses," and afford them little credibility. The right to counsel for indigent contemnors threatened with coercive incarceration should be legislatively or judicially recognized in every jurisdiction, preferably through a clarifying opinion of the U.S. Supreme Court.

The availability of appointed counsel standing alone does not ensure full and fair consideration of the obligor's ability to pay. Appointed counsels are often overburdened and unable to provide the needed level of representation. Researchers who observed child support contempt proceedings in several states reported, "In many of the courtrooms we watched, these attorneys would call out their client's name as the courtroom filled with cases, meeting the client for the first time just prior to the hearing." 248 Reduction of the errors that lead to wrongful incarceration of civil contemnors requires that adequate state resources be devoted to assuring that representation is meaningful. In addition, changes in rules and procedures as noted above are needed to provide the attorney with the tools necessary to obtain justice for low-income child support obligors threatened with imprisonment.

244 See Marjorie A. Caner, Right to Appointment of Counsel in Contempt Proceedings, 32 A.L.R.5th 31, part II, § 3 (Cum. Supp.); see also McBride v. McBride, 431 S.E.2d 14, 19t (1993). Many courts have relied on the Supreme Court's statement in Lassiter v. Dep't of Soc.t Servs., 452 U.S. 18, 25 (1981), that the indigent individual's interest in personal freedom is thet trigger for the right to appointed counsel. See, e.g., Black v. Div. Of Child Support Enforcement, 686 A.2d 164, 167-68 (Del. 1996).t

245 "In making the determination of whether there is a deliberate defiance of the court order, counsel is indispensable." Dube v. Patterson, 481 A.2d 1293, 1295 (Conn. Super. Ct. 1984).

246 Id.; Pasqua v. Council, 892 A.2d 663, 673 (N. J. 2006).

247 See, e.g., Carroll County Bur. of Support v. Brill, No. 05 CA 818, 2005 WL 3489763 (Ohio Ct. App. Dec. 15, 2005) (finding appeal moot because sentence had already been completed); Evans v. Evans, No. 04AP-816, 04AP-1208, 2005 WL 2364976 (Ohio Ct. App. Sept. 27,2005 ) (finding appeal moot because sentence had already been completed); see also supra note 163 .

248 MAY \& Roulet, supra note 13, at 45. 


\section{Conclusion}

There can be no question that the child support enforcement program has proven an effective tool for improving the standard of living of children in single-parent homes. Moreover, the program has also served an important declaratory function by taking seriously the responsibility of a biological parent for the children he or she brings into the world. Integration of this notion into the financial life of the nation is itself a valuable contribution to social policy.

However, the idea of child support orders and their vigorous enforcement as a means to a better life for the children of absent parents has sometimes gotten ahead of the reality. Increasing the amount of a child support award provides no benefit to the child if there is no prospect of payment. In fact, the child may be financially harmed if the overwhelmed parent, unable to pay all that is due, instead pays nothing. Financial harm to the child also may occur if a parent is disabled from providing support by the state's appropriation of an excessive portion of his income to reimburse itself for welfare payments to the custodial parent.

Likewise, harsh enforcement measures provide no benefit to the child if the parent's lack of resources negates the possibility that the measure will result in payment. Harm to the child may result if enforcement mechanisms such as license revocation or imprisonment-imposed on a non-custodial parent who was paying what he could but not all that was ordered-impair the parent's already limited earning capacity. The disconnect between the goals and effects of the child support program as currently implemented demands a re-examination of the statutes, regulations, and practices that contribute to these anomalies.

In addition to the deleterious effects on the well-being of indigent children, the programmatic problems in the child support enforcement system have brought to the fore a long-ignored problem in the use of imprisonment as a sanction for civil contempt. Acceptance of the lack of procedural protections for contemnors facing coercive imprisonment has been based on at least two false assumptions. The first is that there is no need for procedural protections in civil contempt proceedings because any resulting imprisonment is merely conditional, allowing the contemnor to secure his release at any time by meeting the purge condition. The second is that the issues involved in civil contempt are simple, and do not require procedural complexities to protect against aberrant fact-finding.

The Supreme Court rejected the first of these assumptions in Bagwell, but left the second standing. The child support contempt cases demonstrate that the second assumption is also fallacious - that the issues on which the civil contempt finding or the setting of the purge condition are based can be quite complex and difficult of proof. These cases 
also have exposed the fallaciousness of the idea that process can be dispensed with when issues are simple. Child support contemnors have been jailed even when the facts that would prevent this disposition have been acknowledged by the judge. The danger of abuse of the broad discretion accorded the trial judge by current civil contempt law is not affected by the simplicity of the facts.

It may be that procedural protections should extend to all contempt proceedings that can result in imprisonment, as many courts have held in regard to the right to counsel. Whether or not this be the case, the need for greater procedural regularity in child support contempt proceedings is apparent. Flaws in the child support enforcement system create a substantial likelihood that an obligor charged with contempt may lack the means to comply with either or both of the child support order and the purge condition. The cases demonstrate a high risk that under current procedures courts will err in making this determination. A full criminal trial such as the Supreme Court required for the civil contemnors in Bagwell may not be necessary. The procedural adjustments highlighted in this Article are targeted toward some of the primary sources of error in these cases and should form the core of any expansion of the due process rights of child support contemnors. Their implementation would go far toward reducing the risk that low-income child support obligors will continue to be incarcerated for the offense of being poor. 
